Año L. urtea

$126-2018$

Uztaila-abendua Julio-diciembre

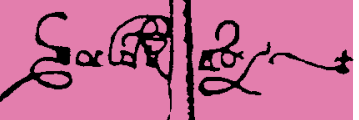
(t)

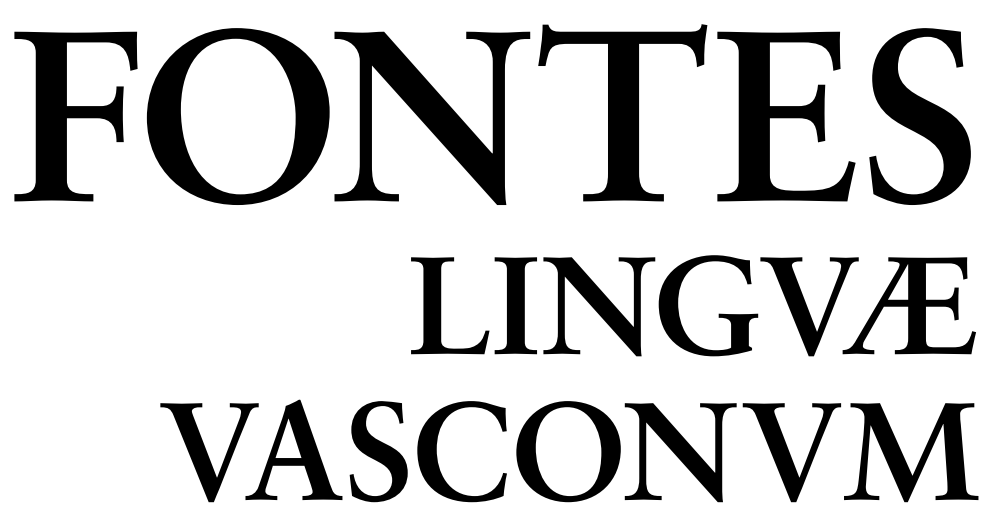

STVDIA ET DOCVMENTA

SEPARATA

Wh-Islands in L2 Spanish and L2 English:

Between Poverty

of the Stimulus

and Data Assessment

Iván Ortega-Santos, Lara Reglero, Jon Franco

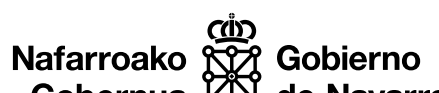

Gobernua LSo de Navarra 


\title{
Wh-Islands in L2 Spanish and L2 English: Between Poverty of the Stimulus and Data Assessment
}

\author{
NZ-irlak H2 gisako gaztelanian eta ingelesean: estimuluen urritasunaren eta datuen \\ analisiaren artean
}

Islas-Q en Español L2 y en Inglés L2: entre la pobreza de estímulo y el análisis de los datos

\author{
Iván ORTEGA-SANTOS \\ University of Memphis \\ rtgsntos@memphis.edu \\ Lara REGLERO \\ Florida State University \\ lreglero@fsu.edu \\ Jon FRANCO \\ University of Deusto \\ franco@deusto.es
}

\begin{abstract}
This paper has been partially supported by Hizkuntzalaritza Teorikorako Taldea (HiTT), Basque Government IT769/13.

Along our voyage as linguists, there stood Jon Ortiz de Urbina, an inspiring Basque syntactician, who became a guiding beacon and a colleague we can always count on. This paper is a tribute to him. We would also like to thank our participants, J. Sprouse, D. Almeida, I. Gómez Soler and S. López Sancio as well as the audience at HLS 2017 for comments and suggestions. B. Morgan deserves separate credit for much needed help with the statistics.Last but not least, we want to express our gratitude to two anonymous reviewers whose comments helped us to improve the paper to a great extent.
\end{abstract}

Submission: 06/04/2018. Provisional acceptance: 18/06/2018. Final acceptance: 04/10/2018. 


\section{ABSTRACT}

This paper sheds light on the acquisition of wh-islands in L2 English spoken by native speakers of Spanish and L2 Spanish spoken by native speakers of English as well as on the distribution of wh-islands in L1 Spanish. A grammaticality judgment task with a 7-point Likert scale provides evidence that wh-island effects are present in L1 and L2 Spanish as well as L1 and L2 English. The L1 Spanish facts challenge the received view of wh-islands in this language, in keeping with recent developments which show that islands are more widely attested across languages than previously thought. These facts also highlight the dialogue between L2 research and replication studies thanks to the use of native control groups.

Keywords: wh-islands; L2 acquisition; data assessment; poverty of the stimulus; experimental syntax.

\section{LABURPENA}

Artikulu honek argitu nahi du nola jabetzen diren NZ-irlez ingelesa $\mathrm{H} 2$ gisa duten gaztelaniadun natiboak eta gaztelania $\mathrm{H} 2$ gisa duten ingelesdun natiboak. Artikuluak, halaber, NZ-irlak arakatzen ditu $\mathrm{H} 1$ gisako gaztelanian. 7 puntuko Likert eskalako gramatikaltasun juzkuei buruzko azterketa batek erakusten du NZ-irla efektuak sortzen direla bai $\mathrm{H} 1$ eta $\mathrm{H} 2$ gisako gaztelanian bai $\mathrm{H} 1$ eta $\mathrm{H} 2$ gisako ingelesean. Bestalde, $\mathrm{H} 1$ gisako gaztelanian lortutako emaitzek zalantzatan jartzen dituzte NZ-irlez tradizioz izan den ikuspegia eta bat egiten dute aspaldi honetako joerekin, zeinek agerian uzten duten lehenago uste zena baino hizkuntza gehiagotan daudela irla sintaktikoak.

Gako hitzak: NZ-irlak; H2ren jabekuntza; datuen analisia; estimuluen urritasuna; sintaxi esperimentala.

\section{RESUMEN}

Este artículo estudia la adquisición de las islas-q en el inglés como L2 hablado por nativos de español y en el español como L2 hablado por nativos de inglés, así como la presencia de islas-q en español como L1. Un estudio de juicios de gramaticalidad con una escala Likert de 7 puntos proporciona evidencia de que los efectos de isla-q están presentes tanto en español como L1 y L2, como en inglés L1 y L2. Los resultados del español como L1 cuestionan la visión tradicional sobre las islas-q en esta lengua. Asimismo también evidencian la importancia del diálogo entre la investigación en L2 y los estudios de réplica o evaluación de datos.

Palabras clave: islas-q; adquisición de L2; evaluación de datos; pobreza del estímulo; sintaxis experimental. 
1. Introduction. 2. The ReCEIVEd VIEW ON WH-ISLANDS IN L1 ENGLiSH AND L1 SPANish. 3. The VIEW From the L2. 4. Methodology. 4.1. Participants. 4.2. Design. 5. RESUlTS. 5.1. Spanish. 5.2. English. 5.3. Linguist versus non-Linguist. 5.4. Basque Spanish vs. Non-Basque Iberian Spanish. 6. DisCussion. 7. CONCLUSION. 8. FutUre WORK. 9. REFERENCES. 10. APPENDIX. RAW DATA AND EXPERIMENTAL STIMULI. 10.1. EXperimental Stimuli. 10.1.1. English - Base Lexicalizations of the Experimental Conditions. 10.1.2. Spanish - Base Lexicalizations of the Experimental Conditions.

\section{INTRODUCTION}

So-called syntactic islands are domains opaque to wh-extraction. The crosslinguistic variation in those island or locality effects, their relation to Universal Grammar (UG) and their acquisition have figured prominently in the theoretical literature (see Boeckx, 2012 for perspective). Here we focus on a subcase of syntactic island, namely, the wh-island, which involves the extraction of a wh-phrase out of an embedded interrogative clause. According to the literature, English is a paradigmatic case of a language where the wh-island constraint is active in contrast to Spanish, which shows a slightly more complex phenomenon in that wh-island effects are constrained to a fewer set of environments than those reported for English (Torrego, 1984), hence the contrast in grammaticality in (1) and $(2)^{1}$ :

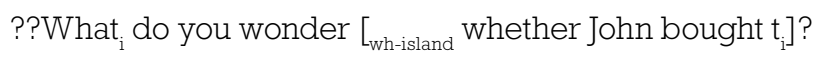

English
¿Qué no sabes $\left[_{\text {wh-island }}\right.$ si Pedro compró $\left.t_{j}\right]$ ?
what not know.2SG if Pedro bought
'What do you wonder whether Pedro bought?'

Spanish

1 The judgment in (2) corresponds to the received view in the theoretical literature; our data. Part of our goals in this paper is to determine its acceptability using experimental data collection methods, therefore, we restrict ourselves to the description in the literature at this point in the paper, for the sake of exposition. 
In her study on the acquisition of wh-islands in second language acquisition, Reglero (2003) used a grammaticality judgment task to determine whether second language learners (sequential bilinguals) can acquire wh-island effects (or lack thereof). According to her results, native speakers of English learning Spanish and native speakers of Spanish learning English both converge with the grammar of the target language, that is, the former are able to learn that the wh-island constraint is not active in Spanish in certain contexts, whereas the latter are able to enforce wh-islands uniformly in English. This result is particularly relevant in the context of generative grammar, as it provides evidence for the access to UG in L2 (second language) acquisition (e. g., see Hawkins \& Chan, 1997; Hawkins, 2000; Epstein, Flynn \& Martohardjono, 1996 and Flynn, 1987 for various proposals concerning the access to UG in L2) given familiar poverty of the stimulus considerations. Specifically, island constraints pertain to the tacit knowledge of the native speakers and are not taught in language classes. It is unclear how parameter resetting could take place, particularly given the absence of negative evidence for L1 (first language) Spanish / L2 English subjects, whose native language allows for island violations as opposed to the target language, unless UG is accessible for L2 learners. In particular, if these subjects were to transfer their native grammar to the target language, the resulting grammar of the target language would be consistent with all the input -their grammar would overgenerate producing structures that in L1 English constitute island violations-, unless L2 learners have full or partial access to UG at the L2 level studied by Reglero (e. g., for instance, under the Full Transfer/Full Access hypothesis, Schwartz \& Sprouse, 1996, at early stages of acquisition transfer would be relevant, though UG can guide L2 acquisition at later stages). Various factors, however, call for further research on this issue. First, Reglero's results show that only $68 \%$ of Spanish L1 speakers accept wh-extraction out of wh-islands, which is not particularly high. Second, recent advances in experimental syntax have unveiled the existence of wh-island effects in closely-related languages, namely, Brazilian Portuguese and Italian (see Almeida, 2014 \& Sprouse, Caponigro, Greco \& Cecheto, 2016 for Italian, respectively). In the former case, the island effects are subliminal, meaning that the island effects are present in the language though the effect does not reach the ungrammaticality threshold, in contrast to the Italian case. Third, López Sancio (2015) also provides evidence for locality restrictions for a subset of wh-island structures in Spanish. Still, López Sancio's study includes wh-islands embedded under the verb preguntarse 'to ask oneself'. Unfortunately, this verb enforces particularly strict locality restrictions on its complement clause -a potentially idiosyncratic behavior of this verb (Torrego, 1984)- and, thus, its behavior might not be fully representative of Spanish. Thus, a study of wh-islands embedded under verbs other than preguntarse is in order. The goals of this research are (i.) to evaluate the results of Reglero (2003); (ii.) to assess the received view of wh-islands in Spanish which considers these to be inactive at least in certain contexts to be discussed below.

Our results show that (i.) the wh-island constraint is more pervasive than previously thought in L1 Spanish; (ii.) L2 Spanish speakers and L2 English speakers converge on the target grammar. Given (i.), the native speakers of Spanish learning English already have the wh-constraint present in their L1 grammar, as opposed to the poverty of the stimulus scenario discussed. In particular, the similarities between L1 Spanish and L1 English can help explain how L2 speakers converge with the target grammars (though access to 
UG would explain it as well -both explanations are not incompatible with one another). Taken together, these results provide further evidence challenging the active vs. inactive island dichotomy taken for granted in syntactic theories of crosslinguistic variation of wh-islands (see Almeida, 2014; Sprouse et al., 2016 and López Sancio, 2015 for related discussion). Moreover, the present research emphasizes the relevance of L2 acquisition studies for current debates on data collection methods in syntax and data assessment in general. Specifically, two data-gathering methods are commonly used in linguistics: (i) non-quantitative processes lacking formal data collection protocols or statistical analysis; and (ii) experimental (formal) methods, as used in other domains of the cognitive sciences. While the traditional approach is found throughout, the second («experimental syntax») is becoming more widespread. As part of this shift, classical theoretical data have been questioned (Edelman \& Christiansen, 2003; Ferreira, 2005; Gibson \& Fedorenko, 2010a, 2010b) and the first large-scale comparisons of the data collected through non-quantitative methods and data collected through experimental methods -data assessment- have been carried out. Sprouse, Schütze and Almeida (2013) found a 95\%, and Sprouse and Almeida (2012), 98\%, convergence rate between traditional judgments and data gathered experimentally for a 10-year period of research in English published in a top journal and an English syntax textbook, respectively. Spanish has not been studied so thoroughly (though see Ortega-Santos \& Uriagereka, 2018 for relevant research). Crucially in the present context, research on L2 includes native speaker control groups for methodological reasons. This entails that $\mathrm{L} 2$ research includes a form of data assessment, even if not discussed as such explicitly. Thus, our research underscores the relevance of the dialogue between the L2 literature and the literature on data collection methods.

Other questions briefly considered for methodological reasons are whether there is microvariation in wh-islands in Basque Spanish as opposed to non-Basque Iberian Spanish. Specifically, we studied the Spanish dialect spoken in the Basque Country and the L2 English of that same population. Thus, we included the comparison between Basque Spanish and non-Basque Iberian Spanish, in case language contact could lead to any divergence in the results. We also considered whether linguists and non-linguists diverge in their results (see Sprouse, 2013 for an overview on research on the latter issue), as part of the participants had training in linguistics.

The paper is organized as follows. In section 2, we discuss the received view of wh-islands in Spanish. Section 3 offers a review of previous research on these constructions in L2 acquisition. Methodological considerations are addressed in section 4, followed by an analysis of the results in section 5 , a discussion in section 6 , a conclusion section and a future work section. The stimuli and other relevant information are included in the appendix.

\section{THE RECEIVED VIEW ON WH-ISLANDS IN L1 ENGLISH AND L1 SPANISH}

Syntactic islands have received significant attention within generative grammar ever since Ross' (1967) seminal work. In this paper we focus on wh-islands, where extraction out of an embedded interrogative wh-clause yields ungrammatical results in lan- 
guages such as English, (3), when compared to the corresponding embedded non-wh clause, (4) (e. g., see Rizzi, 1990, Pesetsky, 1997 and Sprouse et al., 2016; example (1) is repeated for the sake of exposition):

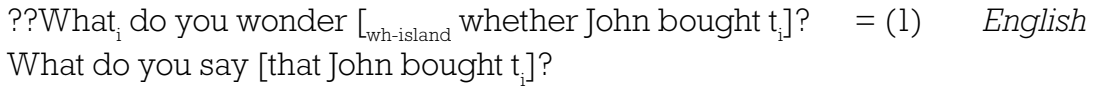

Lately, there has been a shift in the explanation of locality effects. In particular, grammatical theories are being increasingly challenged by so-called processing theories. The former consider islands to be part of the grammar (see Chomsky, 1973 and Rizzi, 1990 for an approach in terms of so-called subjacency and Relativized Minimality, respectively; more recently, see Chomsky's [2013] account in terms of labeling/the Extended Projection Principle (EPP); see Ortega-Santos, 2016 for critical discussion of the latter approach). In turn, the latter consider islands to arise due to the processing complexity of the resulting structures (e. g., Kluender, 2004 and Hofmeister \& Sag, $2010)^{2}$. For current purposes, the exact theoretical machinery responsible for wh-island effects is orthogonal to the argument being made. Rather, we will focus on the acquisition of wh-islands in L2 Spanish and L2 English. In doing so, we will assess whether the received view concerning wh-islands in L1 Spanish (and L1 English) is accurate, which is essentially a data assessment component or a replication study.

Within the received view on wh-islands, these are active in English, but inactive in Spanish (Torrego, 1984), hence the following grammaticality contrast between (3) and (5):

$$
\begin{aligned}
& \text { ¿Qué }{ }_{i} \text { no sabes }\left[_{\text {wh-island }} \text { si Pedro compró } t_{j}\right] \text { ? } \quad \text { Spanish } \\
& \text { what not know.2SG if Pedro bought } \\
& \text { 'What do you wonder whether Pedro bought?' }
\end{aligned}
$$

Torrego's description, however, is slightly more nuanced, in that she shows embedded clauses to constitute an island provided that (i.) the interrogative complementizer heading the embedded clause triggers wh-inversion (hence the contrast in (6) as por qué 'why' does not trigger inversion, in contrast to a quién 'for whom'), or (ii.) the embedded clause is embedded under the verb preguntarse 'wonder', (7) (Torrego, 1984, p. 115 and fn. 25, respectively; her data and judgments) ${ }^{3}$.

2 A third option is that locality constraints are a conventionalized property of the grammar that is functionally grounded (e. g., Berwick \& Weinberg, 1984). For instance, Ortega-Santos (2011) argues that Relativized Minimality is grammaticized as a real constraint that is grounded as a response to memory.

See also Reglero (2011) for an analysis of the acquisition of wh-islands in Spanish under the Minimalist framework.

3 According to an anonymous reviewer, (6a) is unacceptable. If so, his or her grammar may have particularly strict locality properties or else he or she may require inversion with por qué. For discussion on the properties of subject verb inversion under wh-movement, including the case of por qué, see Gallego (2007). 
(6)

a. ¿Qué dices que no te explicas por qué Juan se habrá
what say.2SG that not understand.2SG why Juan RFLX have FUTURE
comprado $t_{i}$ ?

buy.PART

'What do you say that you don't understand why John will have bought?'

b. *QQué dices que no te explicas a quién $n_{x}(l e)$ ha compradojuan $t_{i} t_{x}$ ?

what say.2SG that not understand.2SG to who (CL) have buy.PART Juan

'What do you say that you don't understand for whom John has bought?'

*A quién ${ }_{i}$ te preguntas si ellas entregaron el librot $t_{i}$ ?

To whom RFLX wonder.2SG if they.FEM give.PST.3PL the book

'Who do you wonder if they have given the book to?'

In turn, the wh-inversion or V-preposing rule under wh-movement, which is related to wh-island effects by Torrego, is illustrated in (8) (her data):

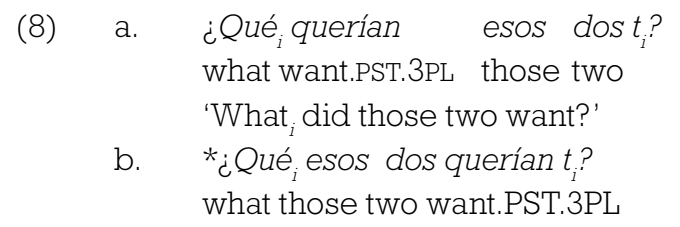

Crucially, Spanish, in contrast to English, has wh-inversion in embedded clauses, see (6)b, as assumed in Torrego's (1984) description of wh-island effects in Spanish presented in this section.

\section{THE VIEW FROM THE L2}

The literature on the L2 acquisition of islands typically focuses on issues such as to what extent parameterized locality principles thought to be part of UG can guide L2 acquisition (e. g., White, 1988) or how parameter resetting takes place (e. g., Uziel, 1993). More specifically, there are two main views regarding UG access in the field of L2 acquisition. According to the first view, also known as the 'No Access hypothesis' (Clahsen \& Muysken, 1986; Schachter, 1988; Bley-Vroman, 1990), L2 learners cannot access UG when acquiring a second language. L2 acquisition is guided by other mechanisms such as problem-solving strategies. Under a related model, L2 learners have partial access to UG. That is, UG can be accessed through the L1, but parameter values cannot be reset. This approach is known as the 'No Parameter Resetting hypothesis', as discussed in Hawkins and Chan (1997) and Hawkins (2000). According to a second view, L2 learners have full access to UG (the 'Full Access hypothesis'), also including the possibility of parameter resetting (Epstein et al., 1996; Flynn, 1987). A variant of this hypothesis is the 'Full Transfer/Full Access hypothesis' (Schwartz \& Sprouse, 1996), which states that both UG and the L1 are responsible for L2 acquisition. That is, the initial state of L2 acquisition corresponds to the entire L1 grammar. When the L1 and L2 differ in their values, UG may guide resetting the relevant parameter from the L1 to the L2 value (Schwartz \& Sprouse, 1996; White, 2003). 
The two main views of UG access have been investigated in the acquisition of (wh)-island constructions. In particular, Bley-Vroman, Felix, \& Ioup (1988), Johnson (1988), Schachter (1989), Johnson and Newport (1991), and Hawkins and Hattori (2006) claim that L2 learners do not access UG or only have partial access in the acquisition of wh-islands. This is based on the non-native judgments of L2 learners in the acquisition of islands in English. According to Johnson (1988), for example, there are critical period effects in the L2 acquisition of island constructions by L1 speakers of Chinese and Spanish. In contrast, Martohardjono (1993), Uziel (1993), White $(1989,2003)$ argue that full access to UG is possible when acquiring islands. For instance, Marohardjono (1993) found that L2 learners (L1 Indonesian, L1 Chinese, and L1 Italian) could identify ungrammatical sentences that violate abstract universal principles. The relevant knowledge, Martohardjono (1993) argues, must come from UG.

Previous studies on English-Spanish bilinguals related to our topic of study, have focused on Torrego's (1984) V-preposing rule, adjunct islands and so-called thattrace effects (Montrul, Foote \& Perpiñán, 2008 for L2 Spanish; see also Reglero, 2003 for that-trace effects as well) or movement restrictions affecting wh-adjuncts (see Turrero-García, 2016 for a study of the interpretation and production of these structures), where the latter are known to be more restrictive than those affecting wh-arguments; in turn, for discussion of wh-scope and wh-copy constructions in the L2 Spanish spoken by native speakers of English, see Liceras, Alba de la Fuente and Walsh $(2011)^{4}$.

A particularly relevant piece of research in the present context is Reglero (2003). Specifically, Reglero focuses on wh-islands (and that-trace effects) in English and Spanish L2 learners (sequential bilinguals), that is to say, our object of study. In her study, three language proficiency groups (beginner, intermediate, and advanced) completed a Grammaticality Judgement Task in written form. Participants were presented with contextualized grammatical/ungrammatical wh-island cases, which had to be judged as either 'good', 'neutral' or 'bad'. The grammatical wh-island cases in Spanish involved extraction of a subject, as in (9), and ungrammatical controls consisted of extraction of an adjunct over a complement, as illustrated in (10) (context is the same in both examples). Note that the English counterpart of (9) is ungrammatical in this language.

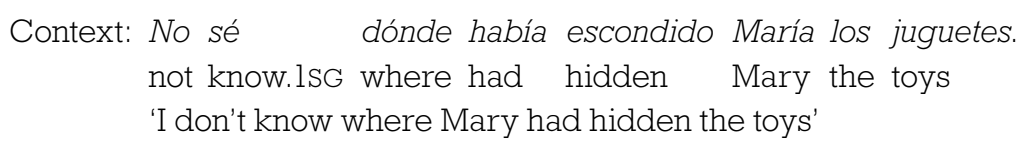

4 Gutiérrez Mangado's (2005) dissertation focuses on long-distance wh-questions in the L2 English of Basque-Spanish bilinguals ranging from 8 to 18 years old. In her oral production task, she found, for instance, so-called wh-copying which is a UG option not present in either the L1 or the L2 input. Thus, she concludes that access to UG is responsible for that data. 


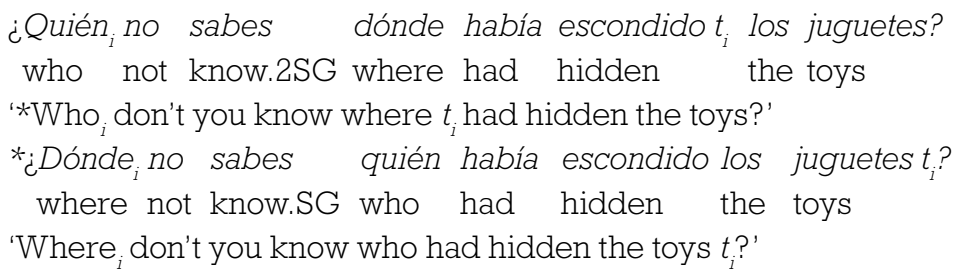

[wh-island ungrammatical]

Based on significant results in acceptability between grammatical and ungrammatical items across all proficiency levels ((9) and (10), respectively), Reglero provides evidence that both L2 speakers converge with the L1 grammars described in section 1 (that is to say, both L1 and L2 English speakers show wh-island effects in (11), whereas L1 and L2 Spanish speakers do not). This result is relevant for our understanding of L2 acquisition and whether UG is accessible to L2 learners for the following reasons: islands pertain to the speaker's tacit knowledge both for L1 and L2 speakers in that they are not explicitly taught. Moreover, while wh-movement across a wh-island, (9), might be present in the Spanish input and, therefore, L2 Spanish speakers may acquire them, these constructions are low frequency structures. The L2 English case is even more problematic, though. In particular, the L1 Spanish grammar can produce both structures that respect the English grammar (long-distance wh-movement across a non-island embedded clause) and structures that violate the English grammar (long-distance wh-movement across an embedded wh-island). Thus, L1 speakers of Spanish learning English need to learn how to be more conservative, how to reduce the generative system in the absence of negative evidence, which is known as a poverty of the stimulus situation ${ }^{5}$. In other words, both grammars are in a superset/subset relation (see the Subset Principle, e. g., in Baker, 1979 and Pinker, 1979) that can be illustrated as follows:

Subset/superset relation in the capacity to generate long-distance wh-movement structures out of an embedded clause in the grammar of English and Spanish

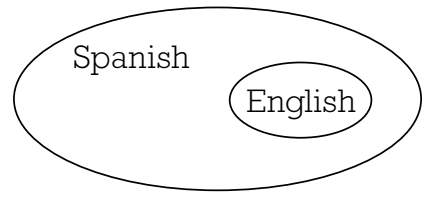

Thus, Reglero concludes that UG can guide the acquisition of wh-islands in English by native speakers of Spanish. This is consistent with previous research providing evidence for access to UG and for parameter resetting in L2 acquistion (e. g. see Dekydspotter, Sprouse \& Anderson, 1997; Dekydspotter \& Sprouse; 2001; Pérez-Leroux \& Glass, 1999; Rothman \& Iverson, 2007; Slabakova, 2006a and Slabakova \&

5 To be explicit, the received view of wh-islands in Spanish (see section 2) revealed the existence of highly selective wh-island effects in Spanish, in contrast to English. Thus, the poverty of the stimulus scenario remains for those contexts where no wh-island effect is present in Spanish, as opposed to English. 
Montrul, 2003; see Slabakova, 2006b for a detailed literature review of studies on this issue; see also the previous discussion in this section).

Within the processing theories of islands, if wh-islands were a processing effect, that is to say, if those islands were hard to process to the point that the perception of acceptability would be low, the same result could follow, provided that crosslinguistic differences can be accounted for (see Arnon, Snider, Hofmeister, Jaeger \& Sag, 2006; Hofmeister \& Sag, 2010 and Ortega-Santos, 2011). Either of those approaches could explain the data; linguistic transfer -without access to UG-, in contrast, would not be able to ${ }^{6}$. This being said, Reglero's evidence that wh-islands are not active in Spanish L1 has to be qualified: Spanish L1 speakers only accepted wh-island cases $68 \%$ of the time, a surprisingly low percentage if wh-islands are not active in the syntactic context studied by Reglero. Moreover, López Sancio (2015), using a 7-point Likert scale and a slightly different data set, provided evidence that wh-island effects are attested in Spanish. Similar evidence has been found in closely-related languages, namely, Brazilian Portuguese and Italian (see Almeida, 2014 and Sprouse et al., 2016, respectively).

Furthermore, it is worth noting that López Sancio's study used preguntarse as the main verb in the wh-island cases (his data):

$$
\begin{aligned}
& \text { ¿Qué } e_{i} \text { te preguntas si Rocío vio } t_{i} \text { ? } \\
& \text { what RFLX wonder.2SG if Rocío saw } \\
& \text { 'What }{ }_{i} \text { do you wonder whether Rocío saw } t_{i} \text { ? }
\end{aligned}
$$

As noted in section 2, preguntarse enforces particularly strict locality restrictions on its complement clause -a potentially idiosyncratic behavior of this verb-and, thus, its behavior might not be fully representative of Spanish (Torrego, 1984). Thus, it is important to control for this independent factor.

Given this state of affairs, our goal is to evaluate the results of Reglero (2003) and the received view on wh-islands in L1 Spanish, so as to establish whether a poverty of the stimulus scenario is indeed attested in L2 English and, thus, whether unambiguous evidence for the role of UG in L2 acquisition is available.

6 Still, transfer explanations are not mutually incompatible with UG access theories, as both approaches can be combined, as noted in this section. 


\section{METHODOLOGY}

\subsection{Participants}

L1 participants were recruited at the educational institutions of the authors and through social media, whereas the L2 participants were recruited through the said educational institutions exclusively. Their participation was strictly voluntary. We restricted ourselves to L1 Iberian Spanish to make sure the data come from a full-pro drop variety ( $c f r$. Toribio, 2000 and Pöll, 2015 for Caribbean Spanish), since the grammaticality of the extraction of wh-subjects out of wh-islands has been argued to co-vary with pro-drop properties (see Chomsky, 2013; judgments for Spanish correspond to Iberian Spanish throughout the paper). L2 English speakers were recruited at the University of Deusto, which means that the participants are speakers of Basque Spanish, potentially with various degrees of Basque-Spanish bilingualism. Thus, for the L1 Spanish control group speakers of Basque Spanish were recruited. Their results were compared to those of speakers of other Iberian varieties of Spanish, just to verify whether there is some microvariation across varieties of Iberian Spanish. We also gathered information concerning the linguistic training of the Spanish L1 participants, as a non-trivial part of them came from the professional network of the authors in contrast to the L2 and English L1 participants. We compared the results of the participants with training in linguistics (e.g., at the MA or BA level or above) to the results of those without any significant training, since the issue of whether linguist and non-linguists or naïve speakers differ in their acceptability judgments has been repeatedly raised by critics of generative grammar, as part of the discussion on experimental/quantitative methods as opposed to more informal data collection methods usually found in this field (see Sprouse 2013 and references therein for an overview). For the rest of the subpopulations (English L1 speakers and the two L2 groups), the chances that they could have training were considered significantly lower and, thus, no information about it was gathered. L2 speakers took placement tests (the Cambridge Test for Adult Learners and a DELE test, for English and Spanish, respectively) after the experiments to determine their level of proficiency in the L2. The results of intermediate and advanced participants were analyzed separately. The participant numbers are as follows:

- L1 Spanish: 37 native speakers; out of these, 13 were speakers of Basque Spanish, 24 were speakers of Iberian dialects other than Basque; 21 had significant linguistics training and 16 had not.

- L1 English: 29 native speakers of American English

- L2 Spanish: 18 intermediate learners; 23 advanced learners

- L2 English: 27 intermediate learners; 29 advanced learners

\subsection{Design}

Following the methodology in Sprouse et al. (2016) and Almeida (2014), a grammaticality judgment task using a 7-point Likert scale was designed for L1 English, L1 Spanish, and the respective L2's. English experimental items were modeled after their work with the addition of the linguistic context, whereas the corresponding Spanish stimuli were translated (stimuli are included in the appendix). Part of the fillers 
correspond to data found in the theoretical literature (with the addition of the context) and part were created for the experiment. In the case of the English fillers, these were mostly borrowed from Almeida's work. Experiments included a factorial design - four conditions to tease apart the effect of the length of the wh-movement from the effect of the presence/absence of the island on the perception of acceptability. (13)a and (13)c exemplify short-distance wh-movement. The embedded clause is a (potential) island only in the latter case, though the wh-movement would not cross it. In turn, (13)b and (13)d exemplify long-distance wh-movement. The embedded clause constitutes a (potential) island for the wh-movement only in the former case (we include preverbal traces of the wh-moved subject even for Spanish for the sake of exposition):

SHORT WH-MOVEMENT, NON-ISLAND

Context: Alguien piensa que Pablo escribió un informe. someone think.3SG that Pablo write.PST.3SG a report 'Someone thinks Paul wrote a report.'

Sentence to evaluate according to the context:
¿Quién $t_{i}$ piensa que Pablo escribio
el informe?
who think.3SG that Pablo write.PST.3SG a report
'Who $t_{i}$ thinks Paul wrote the report?'

b. LONG WH-MOVEMENT, NON-ISLAND

Context: Tú piensas que alguien escribió uninforme, pero no you think.2SG that someone write.PST.3SG a report, but NEG estás totalmente seguro de quién fue.

be.2SG entirely sure of who be.PST.3SG

'You think someone wrote a report, but you are not entirely sure who it was.'

Sentence to evaluate according to the context:

¿Quién piensas que ti escribió el informe?

who think.2SG that write.PST.3SG the report

'Who do you think $t_{i}$ wrote the report?'

c. SHORT WH-MOVEMENT, ISLAND (no violation)

Context: Alguien no sabe porqué Juan escribió el informe. someone not know.3SG why Juan write.PST.3SG the report 'Someone doesn't know why Juan wrote the report.'

Sentence to evaluate according to the context:

¿Quién not $_{i}$ sabe porqué Juan escribió el informe? who not know.3SG why Juan write.PST.3SG the report 'Who $\mathrm{t}_{\mathrm{i}}$ doesn't know why Juan wrote the report?'

d. LONG WH-MOVEMENT, ISLAND (potential violation)

Context: Alguien escribió un informe, pero no sé porqué. someone write.PST a report, but not know.3SG why 'Someone wrote a report, but I don't know why.'

Sentence to evaluate according to the context:

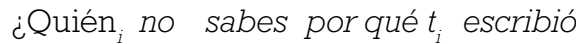
el informe?
who not know why
write.PST.3SG the report
'Who ${ }_{i}$ don't you know why t $t_{i}$ wrote the report?' 
In the words of Sprouse et al (2016, p. 333), the logic in this design is as follows:

Long-distance dependencies tend to be more difficult to process than short-distance dependencies. If this processing difficulty impacts acceptability judgments, then sentences with long-distance dependencies will be rated lower than sentences with short-distance dependencies regardless of whether island constraints are violated. Similarly, island structures often involve more complex structures (e. g., complex NPs) or meanings (e. g., embedded interrogatives). If these structures and/or meanings impact acceptability judgments, sentences containing island structures will be rated lower than sentences that do not contain island structures regardless of whether extraction from islands takes place. What this means in practice is that for an island effect to be a phenomenon in need of a grammatical explanation, the island effect must be defined as a decrease in acceptability over and above the independent decreases caused by the individual components of the sentence.

Acceptability ratings will be able to provide evidence for the presence of island effects under the scenario in (14) below, which shows superadditivity indicated by non-parallel lines:

(14)

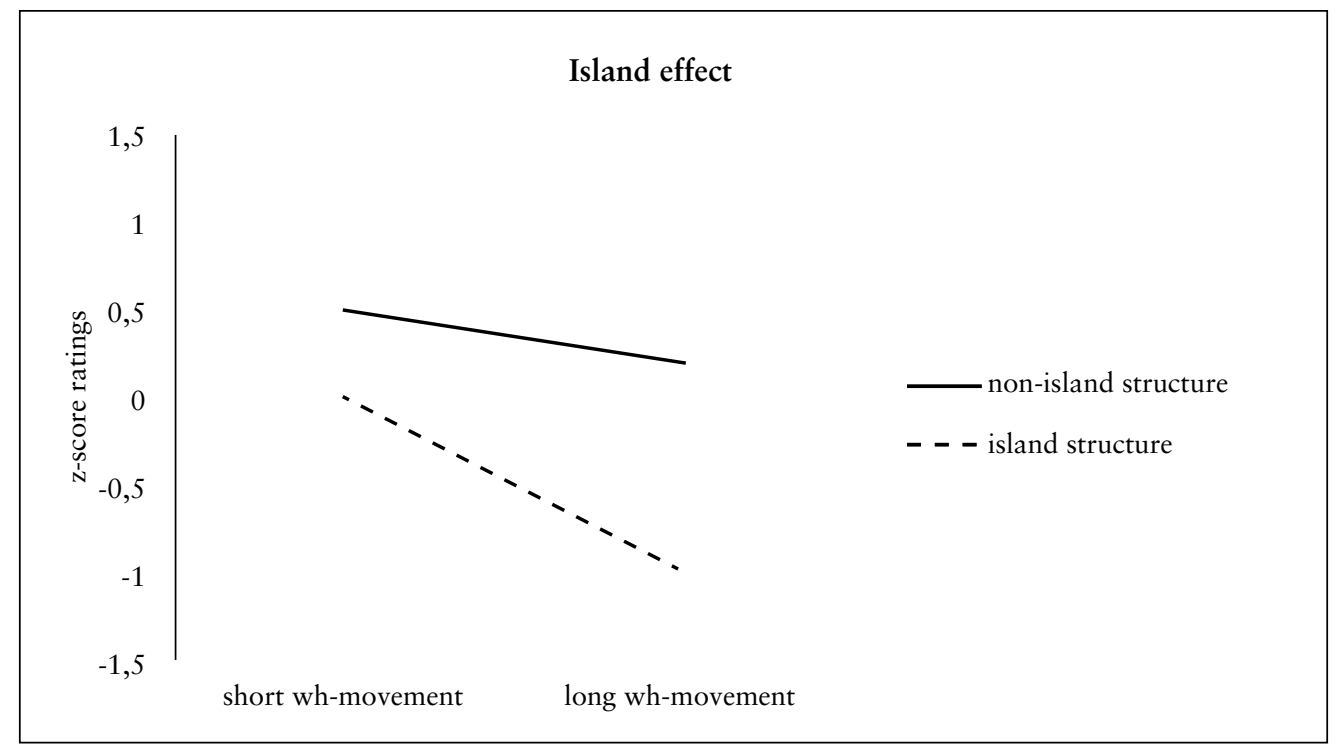

In contrast, the absence of island effects would correspond to the scenario in 15 , indicated by parallel lines (see Sprouse et al., 2016): 
(15)

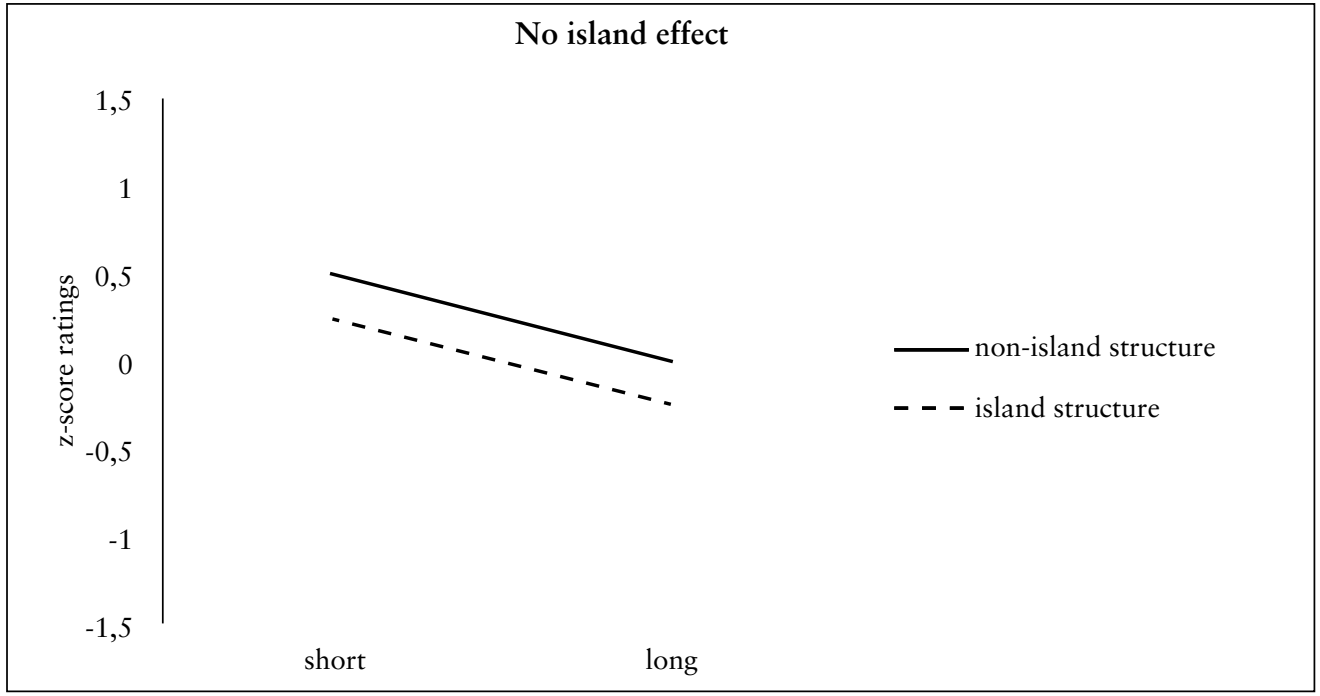

Following Sprouse et al. (2016), we also report the differences-in-differences (DD) score (Maxwell and Delaney, 2003). This score is calculated «by subtracting the difference between two conditions related by one factor from the difference between the two conditions related by the other factor, such as DD $=[(13) a-(13) c]-[(13) b-(13) d]$ (in examples above from this paper). [...] If there is an island effect, the result will be positive, and the size of the number will indicate the size of the island effect in the unit of measure of the ratings» (Sprouse et al., 2016, p. 314)7.

Some remarks concerning the choice of the data set are worth making: we included an intervening wh-item whose morphology unambiguously reveals it is a wh-item as opposed to Spanish si ('if/whether'), used by López Sancio (2015), who followed Sprouse et al. (2016). Specifically, we used por qué 'why'. The choice of the intervening wh-word is also relevant in that Torrego's (1984) proposal argues island effects to be absent when the embedded wh-element does not trigger inversion in the embedded clause, por qué being a case in point. Thus, we can put Torrego's claim to a test, in a way that would not be possible if we had chosen an argumental wh-element. Finally, as noted in the previous section, Torrego (1984, fn. 4) notes that preguntarse in Spanish (the verb used by López Sancio, 2015), bans the extraction from its interrogative complement clause, in contrast to Italian ${ }^{8}$. We chose a different main verb to control for this factor. Moreover, unlike the previous studies (Almeida, 2014; Sprouse et al., 2016 and López Sancio 2015), we included a context for all the sentences in the experiment to make our experiment closer to Reglero's.

\footnotetext{
7 For potential issues with DD scores, see López Sancio (2015, p. 45). Still, we included the results for the readers to be able to compare our work with the multiple wh-island studies which use DD scores.

8 Torrego does not provide an explanation for this behavior and just notes the potentially idiosyncratic property of preguntarse 'wonder'.
} 
10 base lexicalizations were created and these were distributed along ten lists following a Latin Square design. There were 30 fillers and participants saw each condition only once, which resulted in a 15:2 filler/experimental items ratio. The acceptability of the fillers varies widely so participants would use the whole grammaticality scale and there was approximately a 1:1 grammatical / ungrammatical sentences ratio. Experiments were posted on Qualtrics.

After reading the instructions, participants had a 6 sentence practice period. The practice period was similar to the fillers in that the sentences included any kind of structure other than wh-islands. Furthermore, they were designed with various degrees of well-formedness and/or deviance, so as to make participants use the whole scale and not just the extremes. After the practice period, the participants were informed that the experiment would start. The beginning of the experiment consisted in a 10 sentence adaptation period, where the sentences were presented in random order; afterwards, 24 sentences, including the test items were presented in random order.

\section{RESULTS}

We assessed differences in Spanish and English proficiency across four studies (two per language). Each analysis used a $3 \times 2 \times 2$ mixed ANOVA. The between-subject variable was proficiency with three levels (intermediate, advanced, native). The within-subject variables were the length of the wh-movement dependency (Long wh-movement, that is to say, wh-movement originating in the embedded clause, vs. Short wh-movement, that is to say, wh-movement originating in the matrix clause) and the Island vs. Non-island. To avoid scale biases, raw ratings were transformed into z-scores following Sprouse et al. (2016), Almeida (2014) and López Sancio (2015). The discussion is based on the z-scores, though we include the raw data and ANOVA tables based on the raw data for Spanish and English in the appendix for researchers interested in accessing that information.

\section{1. Spanish}

Average ratings and standard deviations for each sentence type in Spanish are reported in Table 1 and the ANOVA table is displayed in Table 2.

Table 1. Mean rates and standard deviations per condition (Spanish)

\begin{tabular}{|l|r|r|r|r|r|r|r|r|}
\hline & \multicolumn{4}{|c|}{ Non-island } & \multicolumn{4}{c|}{ Island } \\
\hline & \multicolumn{2}{|c|}{ Short } & \multicolumn{2}{c|}{ Long } & \multicolumn{2}{c|}{ Short } & \multicolumn{2}{c|}{ Long } \\
\hline & Mean & \multicolumn{1}{|c|}{ SD } & Mean & \multicolumn{1}{c|}{ SD } & Mean & \multicolumn{1}{c|}{ SD } & Mean & \multicolumn{1}{c|}{ SD } \\
\hline Spanish L1 & .824 & .518 & .888 & .466 & .214 & .859 & -.872 & .748 \\
\hline Intermediate L2 Spanish & .071 & 0.791 & .382 & .726 & .215 & .924 & -.032 & .860 \\
\hline Advanced L2 Spanish & .653 & .738 & .307 & .751 & .137 & 1.042 & -.717 & .894 \\
\hline
\end{tabular}


Table 2. ANOvA table for Spanish

\begin{tabular}{|l|r|r|r|c|}
\hline & Df & $F$ & $p$ & $\eta_{p}{ }^{2}$ \\
\hline Main Effects & \multicolumn{5}{|c|}{} \\
\hline Proficiency (L1/L2 level) & 2,75 & 1.09 & 0.342 & 0.028 \\
\hline Island & 1,75 & 65.01 & $<.001$ & 0.464 \\
\hline Length & 1,75 & 21.39 & $<.001$ & 0.222 \\
\hline Interactions & 2,75 & 12.60 & $<.001$ & 0.251 \\
\hline Island * Proficiency & 2,75 & 5.48 & 0.006 & 0.128 \\
\hline Length * Proficiency & 1,75 & 15.94 & $<.001$ & 0.175 \\
\hline Island * Length & 2,75 & 1.538 & 0.221 & 0.039 \\
\hline Island * Length * Proficiency
\end{tabular}

As expected, Non-Island was rated as more grammatically correct than Island, and Short Length was rated higher than Long (but for L1 Spanish, in the latter case), whereas Long + Island condition received the lowest ratings. This is illustrated in the graphs in (16)-(18). Remember that non-parallel lines provide evidence for island effects, whereas parallel lines correspond to the absence of island effects (see section 4; see Sprouse et al.'s, 2016 superadditivity). L1 Spanish shows non-parallel lines and the Long + Island condition received the lowest ratings, a clear instance of an island effect, (16). In the intermediate and advanced L2 Spanish cases, the Short Length ratings differ from L1 Spanish (see the discussion of the statistics for details), but the Long + Island condition received the lowest ratings as well, (17) and (18), respectively.

(16)

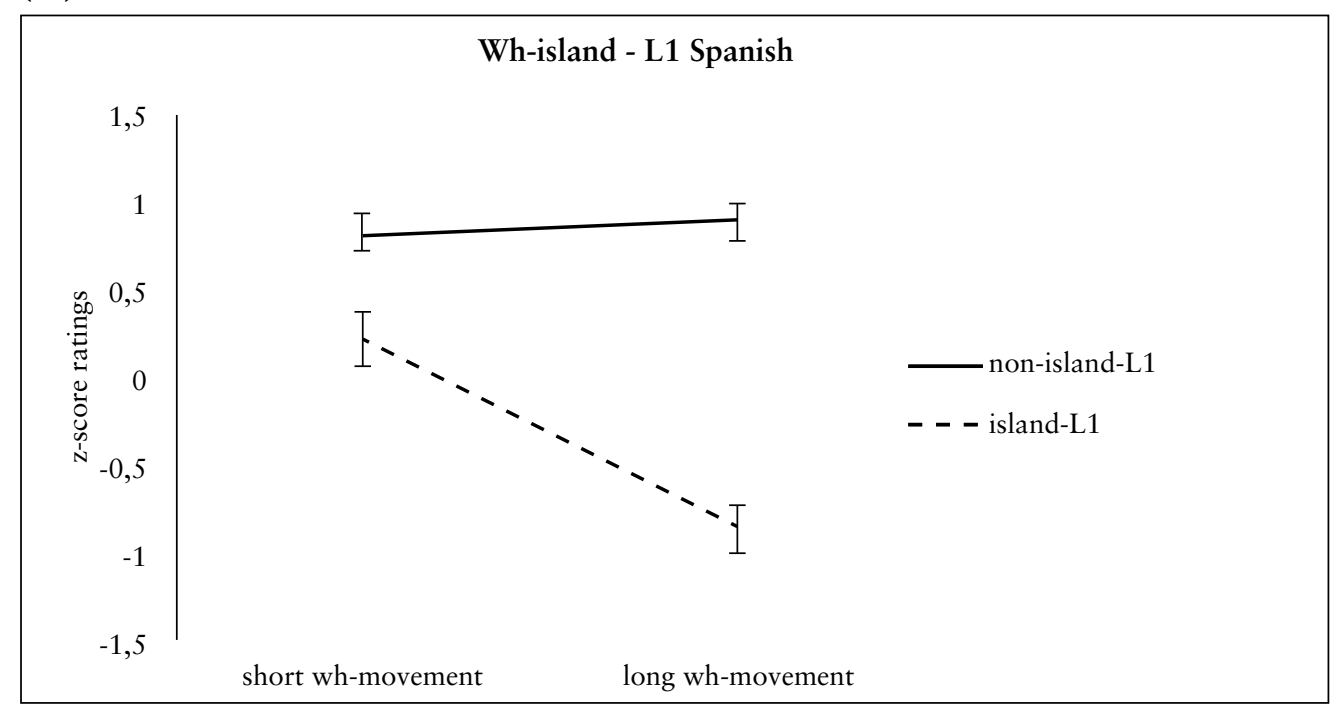


(17)

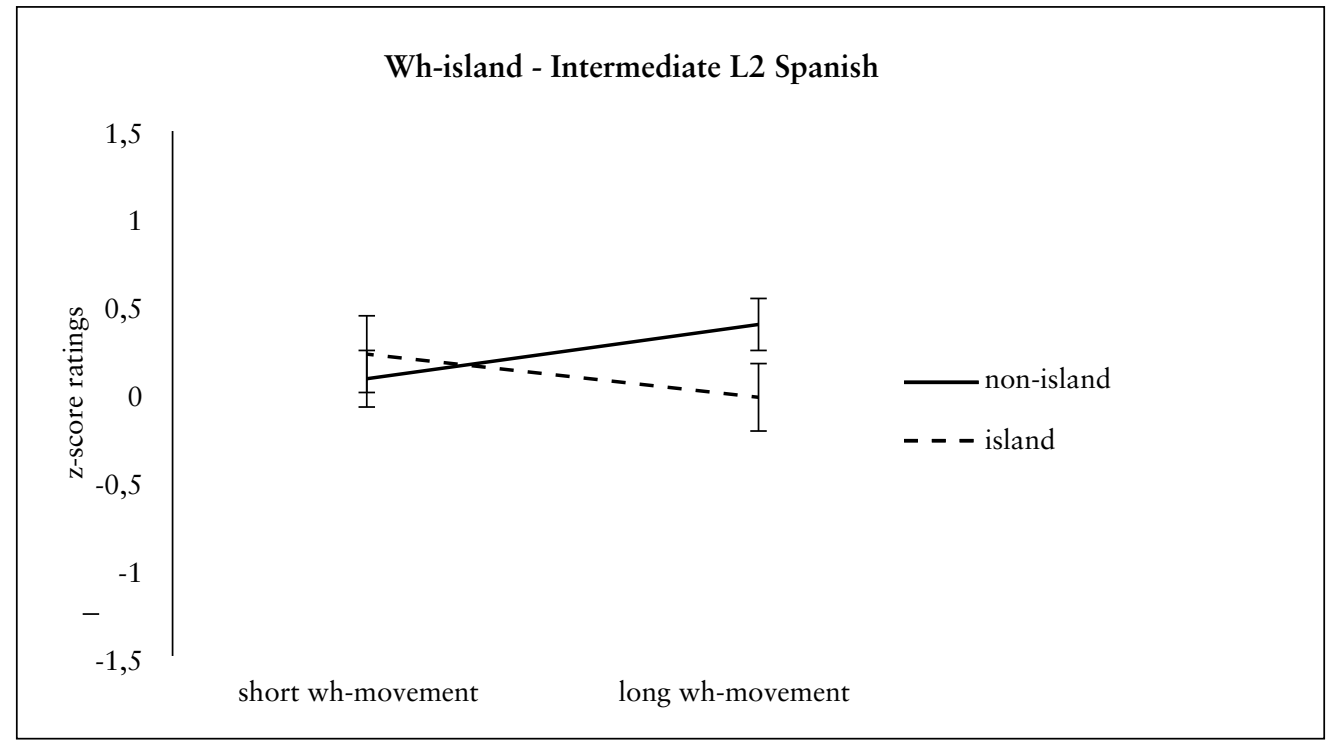

(18)

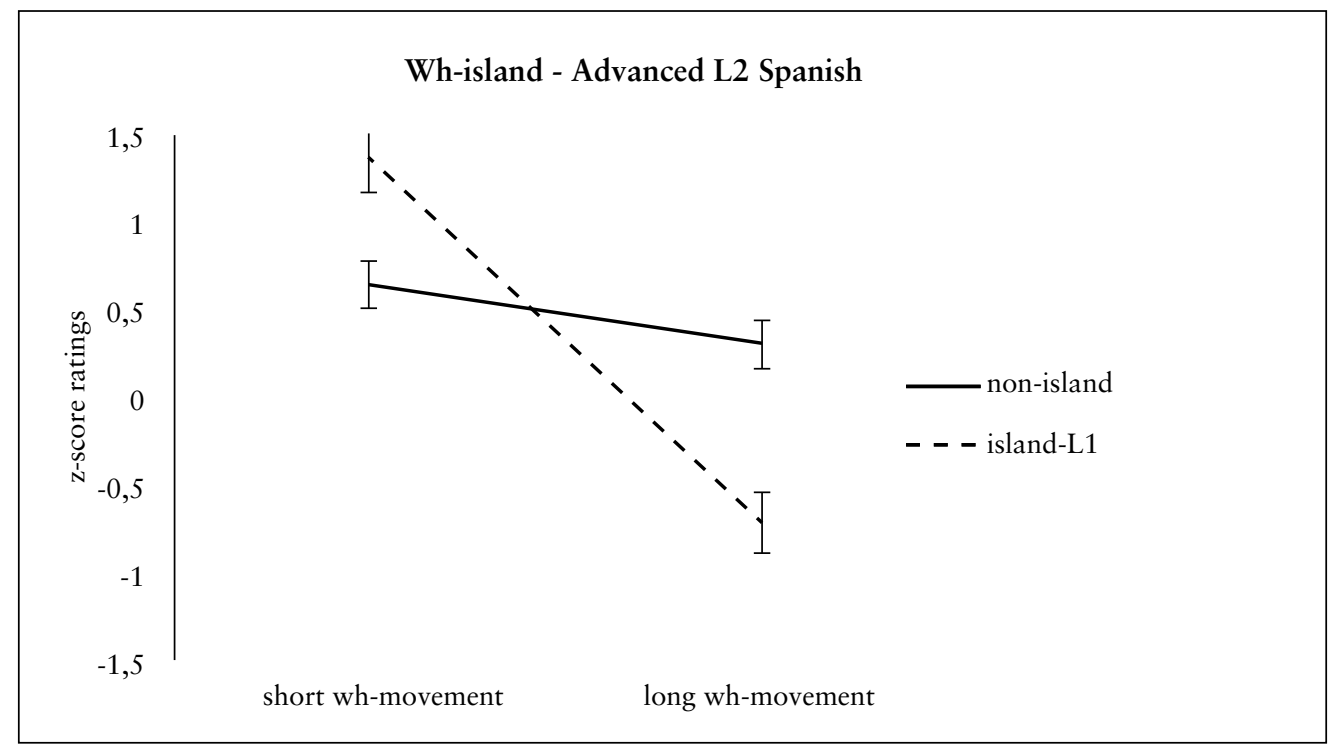

The DD score for L1 Spanish is 1.15; 0.558 for intermediate Spanish; and 0.508 for advanced Spanish. 
For the Island $x$ Length interaction, post-hoc comparisons indicated that there was no difference for Length in the Non-Island condition $(p=.917)$, but Short $>$ Long ( $p$ $<.001)$ in the Island condition. For the Island $\times$ Proficiency interaction, both the Advanced and Native speakers rated Non-Island as more grammatical ( $p<.001$ for both), but the Intermediate speakers rated both Island conditions as equally grammatical $(p=$ .435). For the Length $\times$ Proficiency interaction, both the Advanced and Native speakers rated Short Length as more grammatical ( $p<.001$ for both), but the Intermediate speakers rated both Length conditions as equally grammatical $(p=.835)$.

\subsection{English}

Average ratings and standard deviations for each sentence type in English are reported in Table 3 and the ANOvA table is displayed in Table 4.

Table 3. Mean rates and standard deviations per condition

\begin{tabular}{|l|r|r|r|r|r|r|r|r|}
\hline & \multicolumn{4}{|c|}{ Non-island } & \multicolumn{4}{c|}{ Island } \\
\hline & \multicolumn{2}{|c|}{ Short } & \multicolumn{2}{c|}{ Long } & \multicolumn{2}{c|}{ Short } & \multicolumn{2}{c|}{ Long } \\
\hline & Mean & \multicolumn{1}{|c|}{ SD } & Mean & SD & Mean & SD & Mean & SD \\
\hline English L1 & 1.038 & .580 & 1.248 & .599 & .289 & .773 & -.861 & .769 \\
\hline Intermediate L2 English & .749 & .596 & .471 & .829 & .320 & .879 & -.838 & .692 \\
\hline Advanced L2 English & .983 & .728 & .877 & .557 & .738 & .941 & -.805 & .672 \\
\hline
\end{tabular}

Table 4. ANOVA table for English

\begin{tabular}{|l|c|c|c|c|}
\hline & Df & $F$ & $P$ & $\eta_{\mathrm{p}}{ }^{2}$ \\
\hline Main Effects & \multicolumn{5}{|c|}{} \\
\hline Proficiency & 2,82 & 4.55 & 0.013 & 0.100 \\
\hline Island & 1,82 & 195.75 & $<.001$ & 0.705 \\
\hline Length & 1,82 & 63.36 & $<.001$ & 0.436 \\
\hline Interactions & 2,82 & 4.99 & 0.09 & 0.109 \\
\hline Island * Proficiency & 2,82 & 1.59 & 0.211 & 0.037 \\
\hline Length * Proficiency & 1,82 & 72.95 & $<.001$ & 0.471 \\
\hline Island * Length & 2,82 & 1.44 & 0.242 & 0.034 \\
\hline Island * Length * Proficiency &
\end{tabular}


As in the case of L1 Spanish, Non-Island was rated as more grammatically correct than Island, and Short Length was rated higher than Long (but for L1 English, in the latter case), whereas Long + Island condition received the lowest ratings. This is illustrated in the graphs in (19)-(21), where, again, the non-parallel lines provide evidence for island effects, an effect that is attested in each graph.

(19)

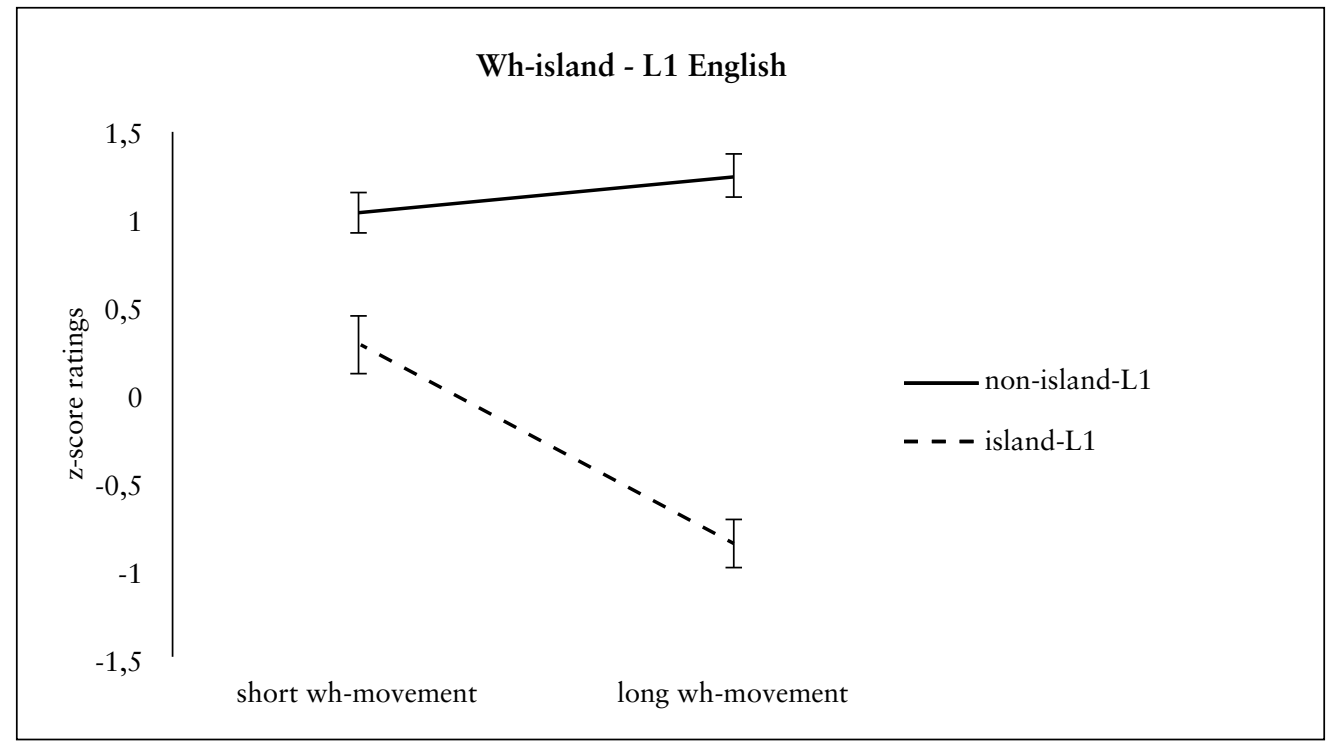

(20)

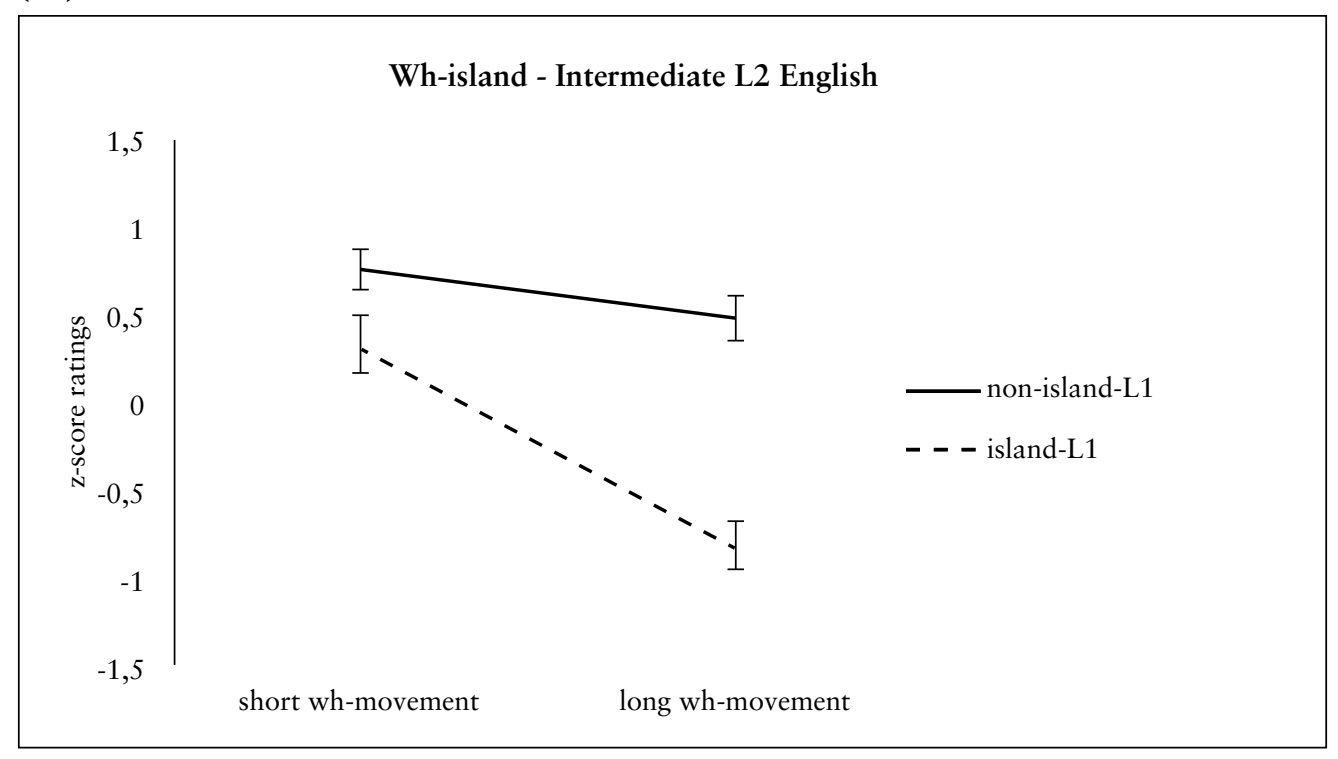


$(21)$

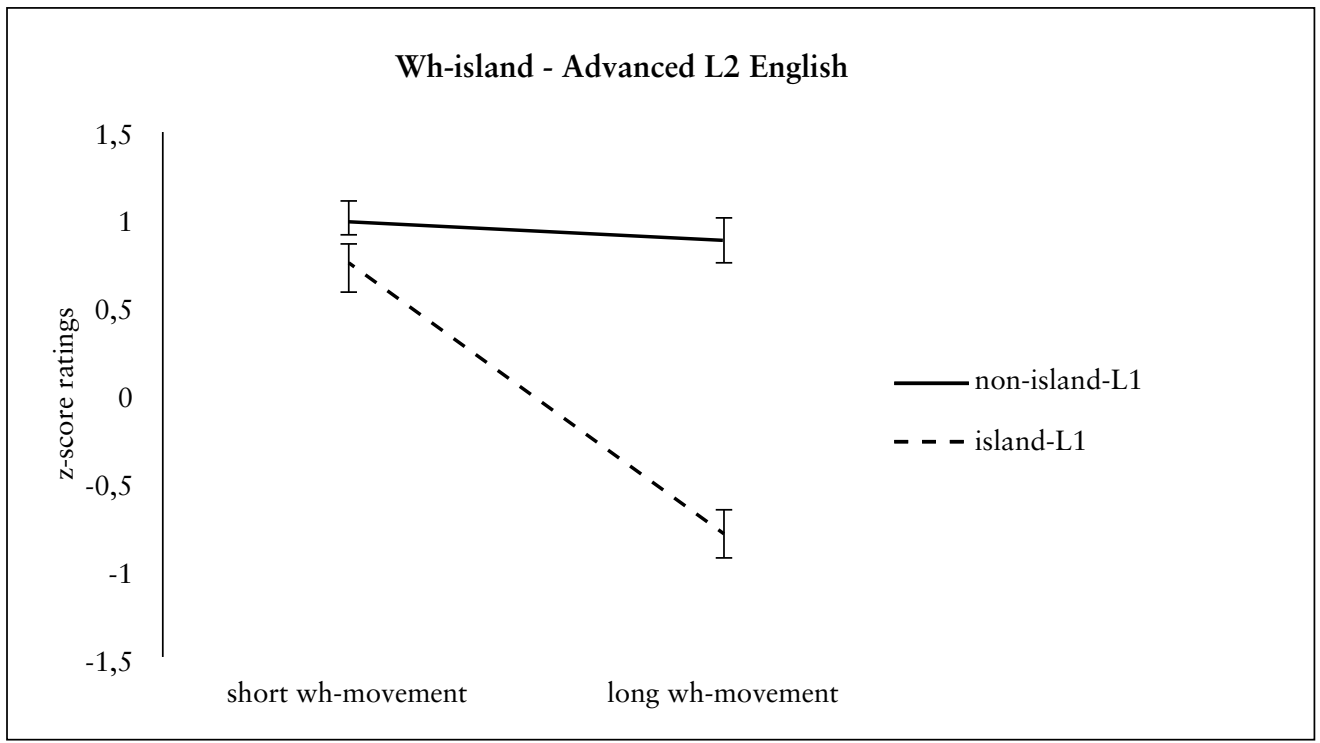

The DD score for L1 English is 1.36; 0.88 for intermediate English; and 1.437 for advanced English. For the Island $\times$ Length interaction, post-hoc comparisons indicated that there was no different for Length in the Non-Island condition $(p=.460)$, but Short wh-movement $>$ Long wh-movement $(p<.001)$ in the Island condition. For the Island $\times$ Proficiency interaction, Native and Advanced speakers gave higher ratings than Intermediate speakers in the Non-Island condition $(p<.031)$, but there were no differences in the Island condition $(p>.052)$. For the Length $\times$ Proficiency interaction, Native speakers rated Long wh-movement (originating from within the embedded clause) as more grammatical than did Intermediate speakers $(p=.003)$, but there were no differences for Short wh-movement (originating from within the matrix clause) $(p=.426)$; however, Advanced speakers were more likely to rate Short wh-movement as more grammatical than were Intermediate speakers $(p=.046)$.

\subsection{Linguist versus non-Linguist}

We assessed differences between linguist versus non-linguist native Spanish speakers. The within-subject variables were the length of the wh-movement (Long vs. Short) and the Island vs Non-Island. The between-subject variable had two levels (Linguist versus Non-linguist).

The descriptives are displayed in Table 5, and the ANOVA table is displayed in Table 6. 
Table 5. Mean rates and standard deviations per condition

\begin{tabular}{|l|c|c|c|c|c|c|c|c|}
\hline & \multicolumn{4}{|c|}{ Non-island } & \multicolumn{4}{c|}{ Island } \\
\hline & \multicolumn{2}{|c|}{ Short } & \multicolumn{2}{c|}{ Long } & \multicolumn{2}{c|}{ Short } & \multicolumn{2}{c|}{ Long } \\
\cline { 2 - 11 } & Mean & SD & Mean & SD & Mean & SD & Mean & SD \\
\hline Non-linguist & 0.83 & 0.582 & 0.77 & 0.609 & 0.37 & 0.998 & -1.13 & 0.662 \\
\hline Linguist & 0.82 & 0.478 & 0.98 & 0.302 & 0.35 & 0.733 & -0.67 & 0.761 \\
\hline
\end{tabular}

Table 6. ANOVA table for Linguist vs Non-linguist

\begin{tabular}{|c|c|c|c|c|}
\hline & df & $F$ & $P$ & $\eta_{p}^{2}$ \\
\hline \multicolumn{5}{|l|}{ Main Effects } \\
\hline Linguist & 1,35 & 3.523 & 0.001 & 0.292 \\
\hline Island & 1,35 & 148.490 & $<.001$ & 0.809 \\
\hline Length & 1,35 & 33.820 & $<.001$ & 0.491 \\
\hline \multicolumn{5}{|l|}{ Interactions } \\
\hline Island * Linguist & 1,35 & 2.078 & 0.158 & 0.056 \\
\hline Length * Linguist & 1,35 & 1.050 & 0.312 & 0.029 \\
\hline Island * Length & 1,35 & 25.039 & $<.001$ & 0.417 \\
\hline Island * Length * Linguist & 1,35 & 0.24 & 0.879 & 0.001 \\
\hline
\end{tabular}

Like the language analyses above, Non-Island was rated as more grammatically correct than Island, and Short Length was rated higher than Long. For the Island $\times$ Length interaction, post-hoc comparisons indicated that there was no difference for Length in the Non-Island condition $(p$.636), but Short wh-movement $>$ Long wh-movement $(p<.001)$ in the Island condition. There were no interactions between the between-subjects variable (Linguist) and either of the within-subjects variables (Island, Length). 


\subsection{Basque Spanish vs. Non-Basque Iberian Spanish}

Last, we assessed differences between Basque versus non-Basque native Spanish speakers. The within-subject variables were the length of the wh-movement (Long vs. Short) and the Presence vs Absence of an island. The between-subject variable had two levels (Basque versus non-Basque). The descriptives are displayed in Table 7, and the ANOVA table is displayed in Table 8.

Table 7. Mean rates and standard deviations per condition

\begin{tabular}{|l|c|c|c|c|c|c|c|c|}
\hline & \multicolumn{4}{|c|}{ Non-island } & \multicolumn{4}{c|}{ Island } \\
\hline & \multicolumn{2}{|c|}{ Short } & \multicolumn{2}{c|}{ Long } & \multicolumn{2}{c|}{ Short } & \multicolumn{2}{c|}{ Long } \\
\hline & Mean & SD & Mean & SD & Mean & SD & Mean & SD \\
\hline Non-Basque & 0.83 & 0.473 & 0.99 & 0.288 & 0.355 & 0.733 & -0.842 & 0.762 \\
\hline Basque & 0.80 & 0.613 & 0.70 & 0.656 & -0.465 & 1.035 & -0.926 & 0.746 \\
\hline
\end{tabular}

Table 8. ANOVA table for Basque Spanish vs. non-Basque Iberian Spanish

\begin{tabular}{|c|c|c|c|c|}
\hline & df & $F$ & $P$ & $\eta_{p}^{2}$ \\
\hline \multicolumn{5}{|l|}{ Main Effects } \\
\hline Basque & 1,35 & 2.136 & 0.153 & 0.058 \\
\hline Island & 1,35 & 129.27 & $<.001$ & 0.787 \\
\hline Length & 1,35 & 28.558 & $<.001$ & 0.449 \\
\hline \multicolumn{5}{|l|}{ Interactions } \\
\hline Island * Basque & 1,35 & 0.158 & 0.693 & 0.005 \\
\hline Length $*$ Basque & 1,35 & 0.26 & 0.872 & 0.001 \\
\hline Island * Length & 1,35 & 20.956 & $<.001$ & 0.375 \\
\hline Island $*$ Length * Basque & 1,35 & 1.520 & 0.226 & 0.042 \\
\hline
\end{tabular}

Once again, Non-Island was rated as more grammatically correct than Island, and Short Length was rated higher than Long. For the Island $\times$ Length interaction, posthoc comparisons indicated that there was no difference for Length in the Non-Island condition $(p=.807)$, but Short $>$ Long $(p<.001)$ in the Island condition. There were no interactions between the between-subjects variable (Basque) and either of the within-subjects variables (Island, Length). 


\section{DISCUSSION}

The data provides evidence for the following:

(a) wh-islands are attested in both L1 English and L1 Spanish; (b.) advanced L2 Spanish speakers are able to acquire the corresponding structures successfully, and both intermediate and advanced L2 English speakers do so, too9. The L1 Spanish data are interesting in that we expanded the inventory of structures considered so far. In particular, we elaborated on previous research on this issue, namely, López-Sancio (2015), by studying a novel context and controlling for an independent factor $(e . g$., we avoided the use of the verb preguntarse 'ask oneself'; see section 4.2 for details). Evidence is provided that wh-elements hosted in an embedded CP give raise to wh-island effects even if the wh-element does not induce subject-verb inversion ( $c f r$. Torrego's 1984 seminal work; though see fn. 3 for a potential interfering factor, namely, the fact that por qué may force subject-verb inversion at least for a subset of the speakers). In that respect, this research adds to a growing body of work on the crosslinguistic variation in wh-island effects by providing experimental evidence that wh-islands are more widely attested across languages than previously thought (Almeida, 2014 and Sprouse et al., 2016). Moreover, the result highlights the importance of L2 acquisition research for the study of data collection methods in syntax: Any divergence between data collected in non-quantitative studies and data collected through experimental methods is particularly relevant, as it may help us understand the source of any hypothetical differencesreplication is, after all, crucial to scientific standards.

With regard to the L2 data, inasmuch as the current results reveal that the wh-island constraint is present in L1 Spanish, it becomes possible to hypothesize that L2 speakers are transferring their L1 grammar when learning English as an L2. The results do not allow us to rule alternative hypotheses: $e . g$., L2 islands may arise not because of transfer, but because L2 learners have access to wh-islands specified by UG (Reglero, 2003). Alternatively, (wh-)islands and locality effects may arise from processing difficulties that affect the perception of acceptability (e. g., Kluender, 2004 and Hofmeister \& Sag, 2010) both in L1 and L2 languages. Nonetheless, our result is a welcome addition to the debate on the role of UG. In particular, recent trends emphasize the need to minimize UG (e. g., Hauser, Chomsky \& Fitch, 2002), thus calling earlier UG-centric approaches to islands into question. The results for L1 English are consistent with previous studies (e. g., see Sprouse et al., 2016). In turn, the L2 Spanish data can receive the same explanation as the L2 English data (though see fn. 9 for discussion of certain nuances). Furthermore, the results did not reveal any difference in the island effects depending on the training in linguistics or the dialect (Basque Spanish / Non-Basque Iberian dialect).

9 L2 English speakers appeared to have a higher L2 level than their L2 Spanish counterparts, a fact that may explain the differences in the behavior of the two intermediate groups. In particular, for the intermediate L2 Spanish speakers, who did not show a statistically significant island effect (though the DD score revealed an island effect), it is hypothesized that their developing grammars prevented them from properly judging the sentences, e.g., because of independent difficulties with the lexicon or the grammar, though this issue may merit further research. 


\section{CONCLUSION}

This research has enhanced our knowledge of the crosslinguistc variation in wh-island effects by providing experimental evidence that wh-islands are more widely attested in Spanish than previously thought (cfr. Torrego's [1984] seminal work). In particular, we elaborated on previous research on this issue, namely, López-Sancio (2015), by studying a novel context and controlling for an independent factor, namely, the choice of the main verb the wh-island is embedded under. López-Sancio used the verb preguntarse 'ask oneself', in spite of the fact that this verb has been argued to show potentially idiosyncratic tight locality constraints. We also use an unambiguously [+wh] complementizer, namely, por qué 'why' as opposed to si 'if', as we hypothesized that this may help L2 speakers detect the potential island. Thus, we expanded the range of contexts studied so far. Our results indicate that Spanish and English both show wh-island effects and that the L2 speakers converge with the target grammar. This is a relevant result in that it adds to our knowledge of the L2 acquisition of the wh-islands, but also it clarifies the Spanish L1 data. Such a clarification was necessary, given that Reglero (2003) showed that the lack of wh-island effects in Spanish L1 was not as clear-cut as one may expect judging from the literature (only $68 \%$ of her Spanish L1 sample found structures involving wh-movement out of a wh-island to be acceptable). Moreover, recent results provided evidence for the existence of L1 Spanish wh-islands in slightly different syntactic context (López Sancio, 2015) and in closely-related languages (see Sprouse et al., 2016 for Italian and Almeida, 2014 for Portuguese). Finally, this research highlights the intersection between the research on L2 acquisition and the debate on data collection methods (see Sprouse, Schütze \& Almeida, 2013). In particular, the use of native control groups in L2 research entails a form of data assessment that can inform the latter line of research.

\section{FUTURE WORK}

Participants rated sentences according to the context provided. Still, questions arise as to the exact interpretation that participants are giving to the sentences, particularly in the L2 (see Turrero-García, 2016 for relevant research on wh-adjuncts in L2 Spanish). Moreover, Torrego's (1984) description of wh-islands in Spanish is linked to a subject-verb inversion rule (a. k. a., V-preposing rule), whose effects provide evidence for successive cyclic wh-movement. In our research, wh-islands are found even when no inversion is attested. A logical step is to study these successive cyclic effects, potential variation in subject-verb inversion with por qué and the relation of these properties to wh-islands. 


\section{REFERENCES}

Almeida, D. (2014). Subliminal wh-islands in Brazilian Portuguese and the consequences for Syntactic Theory. Revista da ABRALIN, 13, 55-93.

Arnon, I., Snider, N., Hofmeister, P., Jaeger, T. \& Sag, I. (2006). Cross-linguistic variation in a processing account: the case of multiple wh-questions. Proceedings of BLS, 32, 23-35.

Baker, C. L. (1979). Syntactic theory and the projection problem. Linguistic Inquiry, 10, 533-581.

Bley-Vroman, R., Felix, S \& Ioup, G. (1988). The accessibility of Universal Grammar in adult language learning. Second Language Research, 4, 1-32.

Bley-Vroman, R. (1990). The logical problem of foreign language learning. Linguistic Analysis, 20, 3-49.

Berwick, R. \& Weinberg, A. (1984). The grammatical basis of linguistic performance. Cambridge, MA: MIT Press.

Boeckx, C. (2012). Syntactic islands. Cambridge: Cambridge University Press.

Chomsky, N. (2013). Problems of projection. Lingua, 130, 33-49.

Chomsky, N. (1973). Conditions on Transformations. In S. Anderson \& P. Kiparsky (eds.), A Festschrift for Morris Halle (p. 232-286). New York: Holt, Rinehart \& Winston.

Clahsen, H. \& Muysken, P. (1986). The availability of Universal Grammar to adult and child learners: A study of the acquisition of German word order. Second Language Research, 2, 93-119.

Dekydspotter, L., Sprouse, R. \& Anderson, B. (1997). The interpretive interface in L2 acquisition: the process-result distinction in English-French interlanguage grammars. Language Acquisition, 6, 297-332.

Dekydspotter, L. \& Sprouse, R. (2001). Mental design and (second) language epistemology: adjectival restrictions on wh-quantifiers and tense in English-French interlanguage. Second Language Research, 17, 1-35.

Epstein, S., Flynn, S. \& Martohardjono, G. (1996). Second language acquisition: Theoretical and experimental issues in contemporary research. Behavioral and Brain Sciences, 19, 677-714.

Flynn, S. (1987). A parameter-setting model of L2 acquisition. Dordrecht: Reidel.

Gallego, Á. (2007). Phase Theory and parametric variation (Unpublished Ph.D. dissertation). Universitat Autonòma de Barcelona.

Gutiérrez Mangado, M. J. (2005). The acquisition of English long distance wh-questions by bilingual Basque/Spanish participants in a school context (Unpublished Ph.D. dissertation). University of the Basque Country.

Hauser, M., Chomsky, N. \& Fitch, W. (2002). The faculty of language: What is it, who has it, and how did it evolve? Science, 298, 1569-1579.

Hawkins, R. (2000). Persistent selective fossilization in second language acquisition and the optimal design of the language faculty. Essex Research Reports in Linguistics, 34, 75-90.

Hawkins, R. \& Chan, Y. (1997). The partial availability of universal grammar in second language acquisition: the 'failed functional features hypothesis'. Second Language Research, 13, 187-226. 
Hawkins, R. \& Hattori, H. (2006). Interpretation of English multiple wh-questions by Japanese speakers: a missing uninterpretable feature account. Second Language Research, 22, 269-301.

Hofmeister, P. \& Sag, I. (2010). Cognitive constraints and island effects. Language, 86, 366-345.

Johnson, J. S. (1988). Critical period effects on universal properties of language: the status of subjacency in the acquisition of a second language (Unpublished Ph.D. dissertation). University of Illinois at Urbana-Champaign.

Johnson, J. S. \& Newport, E. (1991). Critical period effects on universal properties of language: the status of subjacency in the acquisition of a second language. Cognition, 39, 215-158.

Kluender, R. (2004). Are subject islands subject to a processing account? In V. Chand (ed.), Proceedings of 23rd West Coast Conference on Formal Linguistics (p. 475-499). Somerville, MA: Cascadilla Press.

Liceras, J., Alba de la Fuente, A. \& Walsh, L. (2011). Complex Wh-questions in Non-native Spanish and Non-native German: Does input matter? In L. A. Ortiz-Lopez (ed.), Selected Proceedings of the $13^{\text {th }}$ Hispanic Linguistics Symposium (p. 139-149). Somerville, MA: Cascadilla Proceedings Project.

López Sancio, S. (2015). Testing syntactic islands in Spanish (MA Thesis). Universidad del País Vasco/Euskal Herriko Unibertsitatea.

Martohardjono, G. (1993). Wh-Movement in the acquisition of a second language: a cross-linguistic study of 3 languages with and without overt movement (Unpublished Ph.D. dissertation). Cornell University, Ithaca, NY.

Maxwell, S. \& Delaney, H. (2003). Designing experiments and analyzing data: a model comparison perspective. Mahwah: Lawrence Erlbaum Associates.

Montrul, S., Foote, R. \& Perpiñán, S. (2008). Knowledge of wh-movement in Spanish L2 learners and heritage speakers. In J. Bruhn de Garavito \& E. Valenzuela (eds.), Selected Proceedings of the 10th Hispanic Linguistics Symposium (p. 93-106). Somerville, MA: Cascadilla Proceedings Project.

Ortega-Santos, I. (2011). On Relativized Minimality, memory and cue-based parsing. Iberia: International Journal of Theoretical Linguistics, 3, 35-64.

Ortega-Santos, I. (2016). Focus-related operations at the right edge in the grammar of Spanish: Subjects and ellipsis. Amsterdam/Philadelphia: John Benjamins.

Ortega-Santos, I. \& Uriagereka, J. (2018). A look at microvariation in theoretical syntax: dialect distance and data assessment in Chilean, Venezuelan and Puerto Rican Spanish. Ms. University of Memphis.

Pérez-Leroux, A. T. \& Glass, W. (1999). OPC effects on the L2 acquisition of Spanish. In Pérez-Leroux \& Glass (eds.), Contemporary Perspectives on the Acquisition of Spanish, volume 1: Developing Grammars (p. 149-165). Somerville, MA: Cascadilla Press.

Pinker, S. (1979). Formal models of language learning. Cognition, 7, 217-283.

Pöll, B. (2015). Caribbean Spanish = Brazilian Portuguese? Some comparative thoughts on the loss of pro-drop. Studies in Hispanic and Lusophone Linguistics, $8,317-354$.

Reglero, L. (2003). Resetting parameters in the acquisition of a second language. ASJU, $37,157-202$. 
Reglero, L. (2011). A minimalist approach to locality constraints in Second Language Acquisition. In M.C. Morúa Leyva \& G. López Cruz (eds.), Estudios morfológicos, sintácticos, semánticos y de lingüística aplicada (p. 191-209). Hermosillo, Sonora: Editorial Universidad de Sonora.

Rizzi, L. (1990). Relativized Minimality. Cambridge, MA: MIT Press. (Linguistic Inquiry Monograph, 16).

Ross, J. (1967). Constraints on variables in syntax (Ph.D. Diss.). MIT.

Rothman, J. \& Iverson M. (2007). Input type and parameter resetting: is naturalistic input necessary? IRAL, 45, 285-319.

Schachter, J. (1988). Second language acquisition and its relationship to Universal Grammar. Applied Linguistics, 9, 219-235.

Schachter, J. (1989). Testing a proposed universal. In S. M. Gass \& J. Schachter (eds.), Linguistic perspectives on second language acquisition (p. 73-88). Cambridge: Cambridge University Press.

Schwartz, B. D. \& Sprouse, R. A. (1996). L2 cognitive states and the full transfer/full access model. Second Language Research, 12, 40-72.

Slabakova, R. (2006a). Is there a critical period for semantics? Second Language Research, 22, 302-338.

Slabakova, R. (2006b). Learnability in the L2 acquisition of semantics: a bidirectional study of a semantic parameter. Second Language Research, 22, 498-523.

Slabakova, R. \& Montrul, S. (2003). Genericity and aspect in L2 acquisition. Language Acquisition, 11, 165-196.

Sprouse, J. (2013). Acceptability judgments. Oxford Bibliographies Online: Linguistics. Retrieved from http://www.oxfordbibliographies.com/view/document/ obo-9780199772810/obo-9780199772810-0097.xml.

Sprouse, J., Schütze, C. \& Almeida D. (2013). Assessing the reliability of journal data in syntax: Linguistic Inquiry 2001-2010. Lingua, 134, 219-248.

Sprouse, J., Caponigro, I., Greco, C \& Cechetto, C. (2016). Experimental syntax and the variation of island effects in Italian and English. Natural Language and Linguistic Theory, 34, 307-344.

Toribio, A. (2000). Setting parametric limits on dialectal variation in Spanish. Lingua, $110,315-341$.

Torrego, E. (1984). On inversion in Spanish and some of its effects. Linguistic Inquiry, $15,103-129$.

Turrero Garcia, M. (2016). How far can they go? Non-native speakers of Spanish and wh-questions (Ph.D. Diss.). University of Massachusetts, Amherst.

Uziel, S. (1993). Resetting Universal Grammar parameters: evidence from second language acquisition of Subjacency and the Empty Category Principle. Second Language Research, 9(1), 49-83.

White, L. (1988). Island effects in second language acquisition. In S. Flynn \& W. O’Neil (eds.), Linguistic theory in second language acquisition (pp. 144-172). Dordrecht: Kluwer.

White, L. (1989). Universal grammar and second language acquisition. John Bejamins: Amsterdam.

White, L. (2003). Second language acquisition and universal grammar. Cambridge: Cambridge University Press. 


\section{APPENDIX. RAW DATA AND EXPERIMENTAL STIMULI}

Table 1. Mean rates and standard deviations per condition for Spanish - raw data

\begin{tabular}{|l|c|c|c|c|c|c|c|c|}
\hline & \multicolumn{4}{|c|}{ Non-island } & \multicolumn{4}{c|}{ Island } \\
\hline & \multicolumn{2}{|c|}{ Short } & \multicolumn{2}{c|}{ Long } & \multicolumn{2}{c|}{ Short } & \multicolumn{2}{c|}{ Long } \\
\hline & Mean & SD & Mean & SD & Mean & SD & Mean & SD \\
\hline Spanish L1 & 6.30 & 1.222 & 6.43 & 1.015 & 4.89 & 2.011 & 2.19 & 1.713 \\
\hline Intermediate L2 Spanish & 4.94 & 1.731 & 5.44 & 1.338 & 5.06 & 1.514 & 4.78 & 1.833 \\
\hline Advanced L2 Spanish & 5.96 & 1.461 & 5.35 & 1.555 & 4.91 & 1.929 & 3.00 & 1.954 \\
\hline
\end{tabular}

Table 2. ANOVA table for Spanish - raw data

\begin{tabular}{|l|c|c|c|c|}
\hline & Df & $F$ & $p$ & $\eta_{\mathbf{p}}{ }^{2}$ \\
\hline Main Effects & \multicolumn{1}{|c|}{} \\
\hline Proficiency (L1/L2 level) & 2,75 & 0.38 & 0.686 & 0.010 \\
\hline Island & 1,75 & 76.68 & $<.001$ & 0.506 \\
\hline Length & 1,75 & 25.44 & $<.001$ & 0.253 \\
\hline Interactions & 2,75 & 16.79 & $<.001$ & 0.309 \\
\hline Island * Proficiency & 2,75 & 7.21 & 0.001 & 0.161 \\
\hline Length * Proficiency & 1,75 & 17.54 & $<.001$ & 0.190 \\
\hline Island * Length & 2,75 & 2.89 & 0.062 & 0.072 \\
\hline Island * Length * Proficiency & & & & \\
\hline
\end{tabular}

Table 3. Mean rates and standard deviations per condition for English - raw data

\begin{tabular}{|l|c|c|c|c|c|c|c|c|}
\hline & \multicolumn{4}{|c|}{ Non-island } & \multicolumn{4}{c|}{ Island } \\
\hline & \multicolumn{2}{|c|}{ Short } & \multicolumn{2}{c|}{ Long } & \multicolumn{2}{c|}{ Short } & \multicolumn{2}{c|}{ Long } \\
\hline & Mean & SD & Mean & SD & Mean & SD & Mean & SD \\
\hline English L1 & 5.93 & 1.252 & 6.34 & 1.233 & 4.52 & 1.883 & 1.97 & 1.451 \\
\hline Intermediate L2 English & 5.52 & 1.221 & 5.00 & 1.641 & 4.67 & 1.961 & 2.26 & 1.318 \\
\hline Advanced L2 English & 5.97 & 1.451 & 5.69 & 1.285 & 5.34 & 1.818 & 2.14 & 1.329 \\
\hline
\end{tabular}


Table 4. ANOVA table for English - raw data

\begin{tabular}{|l|r|r|r|r|}
\hline & Df & $F$ & $P$ & $\eta_{p}{ }^{2}$ \\
\hline Main Effects \\
\hline Proficiency & 2,82 & 1.99 & 1.43 & 0.046 \\
\hline Island & 1,82 & 206.26 & $<.001$ & 0.716 \\
\hline Length & 1,82 & 70.58 & $<.001$ & 0.463 \\
\hline Interactions & 2,82 & 4.38 & 0.016 & 0.097 \\
\hline Island * Proficiency & 2,82 & 1.36 & $<.001$ & 0.032 \\
\hline Length * Proficiency & 1,82 & 79.27 & $<.001$ & 0.492 \\
\hline Island * Length & 2,82 & 1.43 & 0.244 & 0.034 \\
\hline Island * Length * Proficiency
\end{tabular}

\subsection{Experimental Stimuli}

\subsubsection{English - Base Lexicalizations of the Experimental Conditions}

(1) Paradigm 1

a. SHORT WH-MOVEMENT, NON-ISLAND

Context: Someone thinks Paul wrote a report.

Sentence to evaluate according to the context: Who thinks Paul wrote the report?

b. SHORT WH-MOVEMENT, ISLAND (no violation)

Context: Someone doesn't know why Paul wrote the report.

Sentence to evaluate according to the context: Who doesn't know why Paul wrote the report?

C. LONG WH-MOVEMENT, NON-ISLAND

Context: You think someone wrote a report, but you're not entirely sure who it was.

Sentence to evaluate according to the context: Who do you think wrote the report?

d. LONG WH-MOVEMENT, ISLAND (potential violation)

Context: Someone wrote a report, but I don't know why.

Sentence to evaluate according to the context: Who don't you know why wrote the report?

(2) Paradigm 2

a. SHORT WH-MOVEMENT, NON-ISLAND

Context: Someone thinks Andrew wrote a song.

Sentence to evaluate according to the context: Who thinks Andrew wrote the song?

b. SHORT WH-MOVEMENT, ISLAND (no violation)

Context: Someone doesn't know why Andrew wrote a song. 
Sentence to evaluate according to the context: Who doesn't know why Andrew wrote the song?

c. LONG WH-MOVEMENT, NON-ISLAND

Context: You think someone wrote a song, but you're not sure who it was. Sentence to evaluate according to the context: Who do you think wrote the song?

d. LONG WH-MOVEMENT, ISLAND (potential violation)

Context: Someone wrote a song, but I don't know why. Sentence to evaluate according to the context: Who don't you know why wrote the song?

(3) Paradigm 3

a. SHORT WH-MOVEMENT, NON-ISLAND

Context: Someone thinks that Robert washed the clothes.

Sentence to evaluate according to the context: Who thinks Robert washed the clothes?

b. SHORT WH-MOVEMENT, ISLAND (no violation)

Context: Someone doesn't know why Robert washed the clothes.

Sentence to evaluate according to the context: Who doesn't know why Robert washed the clothes?

C. LONG WH-MOVEMENT, NON-ISLAND

Context: You think someone washed the clothes, but you're not sure who it was.

Sentence to evaluate according to the context: Who do you think washed the clothes?

d. LONG WH-MOVEMENT, ISLAND (potential violation)

Context: Someone washed the clothes, but I don't know why. After all, they were not dirty.

Sentence to evaluate according to the context: Who don't you know why washed the clothes?

(4) Paradigm 4

a. SHORT WH-MOVEMENT, NON-ISLAND

Context Someone thinks that Scott swept the floor.

Sentence to evaluate according to the context: Who thinks Scott swept the floor?

b. SHORT WH-MOVEMENT, ISLAND (no violation)

Context: Someone doesn't know why Scott swept the floor.

Sentence to evaluate according to the context: Who doesn't know why Scott swept the floor?

c. LONG WH-MOVEMENT, NON-ISLAND

Context: You think someone swept the floor, but you're not sure who it was.

Sentence to evaluate according to the context: Who do you think swept the floor?

d. LONG WH-MOVEMENT, ISLAND (potential violation)

Context: Someone swept the floor, but I don't know why.

Sentence to evaluate according to the context: Who don't you know why swept the floor?

464 Fontes Linguae Vasconum (FLV), 126, julio-diciembre, 2018, 435-471

ISSN: 0046-435X ISSN-e: 2530-5832 
(5) Paradigm 5

a. SHORT WH-MOVEMENT, NON-ISLAND

Context: Someone thinks that Joe opened the door.

Sentence to evaluate according to the context: Who thinks Joe opened the door?

b. SHORT WH-MOVEMENT, ISLAND (no violation)

Context: Someone doesn't know why Joe opened the door.

Sentence to evaluate according to the context: Who doesn't know why Joe opened the door?

C. LONG WH-MOVEMENT, NON-ISLAND

Context: You think someone opened the door, but you're not sure who it was. Sentence to evaluate according to the context: Who do you think opened the door?

d. LONG WH-MOVEMENT, ISLAND (potential violation)

Context: Someone opened the door, but I don't know why. Sentence to evaluate according to the context: Who don't you know why opened the door?

(6) Paradigm 6

a. SHORT WH-MOVEMENT, NON-ISLAND

Context: Someone thinks that Edward received the award.

Sentence to evaluate according to the context: Who thinks Edward received the award?

b. SHORT WH-MOVEMENT, ISLAND (no violation)

Context: Someone doesn't know why Edward received the award.

Sentence to evaluate according to the context: Who doesn't know why Edward received the award?

c. LONG WH-MOVEMENT, NON-ISLAND

Context: You think someone got an award, but you're not sure who it was. Sentence to evaluate according to the context: Who do you think received the award?

d. LONG WH-MOVEMENT, ISLAND (potential violation)

Context: Someone received an award, but I don't know why. Sentence to evaluate according to the context: Who don't you know why received the award?

(7) Paradigm 7

a. SHORT WH-MOVEMENT, NON-ISLAND

Context: Someone thinks that Kevin copied the exam.

Sentence to evaluate according to the context: Who thinks Kevin copied the exam?

b. SHORT WH-MOVEMENT, ISLAND (no violation)

Context: Someone doesn't know why Kevin copied the exam. Truth be told, it was very easy.

Sentence to evaluate according to the context: Who doesn't know why Kevin copied the exam? 
C. LONG WH-MOVEMENT, NON-ISLAND

Context: You think someone copied the exam, but you're not entirely sure who it was.

Sentence to evaluate according to the context: Who do you think copied the exam?

d. LONG WH-MOVEMENT, ISLAND (potential violation)

Context: Somebody copied the exam, but I don't know why. After all, it was very easy.

Sentence to evaluate according to the context: Who don't you know why copied the exam?

(8) Paradigm 8

a. SHORT WH-MOVEMENT, NON-ISLAND

Context: Someone thinks that Tom painted the wall.

Sentence to evaluate according to the context: Who thinks Tom painted the wall?

b. SHORT WH-MOVEMENT, ISLAND (no violation)

Context: Someone doesn't know why Tom painted the wall. Truth be told, it did not look that bad.

Sentence to evaluate according to the context: Who doesn't know why Tom painted the wall?

c. LONG WH-MOVEMENT, NON-ISLAND

Context: You think someone painted the wall, but you're not sure who it was.

Sentence to evaluate according to the context: Who do you think painted the wall?

d. LONG WH-MOVEMENT, ISLAND (potential violation)

Context: Someone painted the wall, but I don't know why. After all, it did not look that bad.

Sentence to evaluate according to the context: Who don't you know why painted the wall?

(9) Paradigm 9

a. SHORT WH-MOVEMENT, NON-ISLAND

Context: Someone thinks that Fred stole the money.

Sentence to evaluate according to the context: Who thinks Fred stole the money?

b. SHORT WH-MOVEMENT, ISLAND (no violation)

Context: Someone doesn't know why Fred stole the money. Truth be told, he is rich.

Sentence to evaluate according to the context: Who doesn't know why Fred stole the money?

c. LONG WH-MOVEMENT, NON-ISLAND

Context: You think someone stole the money, but you're not entirely sure who it was.

Sentence to evaluate according to the context: Who do you think stole the money? 
d. LONG WH-MOVEMENT, ISLAND (potential violation)

Context: Somebody stole the money, but I don't know why. After all, nobody here lacks anything.

Sentence to evaluate according to the context: Who don't you know

(10) Paradigm 10 why stole the money?

a. SHORT WH-MOVEMENT, NON-ISLAND

Context: Someone thinks David pruned the roses.

Sentence to evaluate according to the context: Who thinks David pruned the roses?

b. SHORT WH-MOVEMENT, ISLAND (no violation)

Context: Someone doesn't know why David pruned the roses. Truth be told, the rosebush did not look so bad.

Sentence to evaluate according to the context: Who doesn't know why David pruned the roses?

c. LONG WH-MOVEMENT, NON-ISLAND

Context: You think someone pruned the roses, but you're not entirely sure who it was.

Sentence to evaluate according to the context: Who do you think pruned the roses?

d. LONG WH-MOVEMENT, ISLAND (potential violation)

Context: Someone pruned the roses, but I don't know why. After all, the rosebush did not look so bad.

Sentence to evaluate according to the context: Who don't you know why pruned the roses?

\subsubsection{Spanish - Base Lexicalizations of the Experimental Conditions (see the English counterparts for the translation)}

(1) Paradigm 1

a. SHORT WH-MOVEMENT, NON-ISLAND

Context: Alguien piensa que Pablo escribió un informe.

Sentence to evaluate according to the context: ¿Quién piensa que Pablo escribió el informe?

b. SHORT WH-MOVEMENT, ISLAND (no violation)

Context: Alguien no sabe por qué Juan escribió el informe.

Sentence to evaluate according to the context: ¿Quién no sabe por qué Juan escribió el informe?

c. LONG WH-MOVEMENT, NON-ISLAND

Context: Tú piensas que alguien escribió un informe, pero no estás totalmente seguro de quién fue.

Sentence to evaluate according to the context: ¿Quién piensas que escribió el informe?

d. LONG WH-MOVEMENT, ISLAND (potential violation)

Context: Alguien escribió un informe pero no sé por qué.

Sentence to evaluate according to the context: ¿Quién no sabes por qué escribió el informe? 
(2) Paradigm 2

a. SHORT WH-MOVEMENT, NON-ISLAND

Context: Alguien piensa que Andrés compuso una canción. Sentence to evaluate according to the context: ¿Quién piensa que Andrés compuso una canción?

b. SHORT WH-MOVEMENT, ISLAND (no violation)

Context: Alguien no sabe por qué Andrés compuso una canción. Sentence to evaluate according to the context: ¿Quién no sabe por qué Andrés compuso una canción?

c. LONG WH-MOVEMENT, NON-ISLAND

Context: Tú piensas que alguien compuso una canción, pero no estás totalmente seguro de quién fue.

Sentence to evaluate according to the context: ¿Quién piensas que compuso la canción?

d. LONG WH-MOVEMENT, ISLAND (potential violation)

Context: Alguien compuso una canción, pero no sé por qué.

Sentence to evaluate according to the context: ¿Quién no sabes por qué compuso la canción?

(3) Paradigm 3

a. SHORT WH-MOVEMENT, NON-ISLAND

Context: Alguien piensa que Javier lavó la ropa.

Sentence to evaluate according to the context: ¿Quién piensa que Javier lavó la ropa?

b. SHORT WH-MOVEMENT, ISLAND (no violation)

Context: Alguien no sabe por qué Javier lavó la ropa. La verdad es que no estaba particularmente sucia.

Sentence to evaluate according to the context: ¿Quién no sabe por qué Javier lavó la ropa?

c. LONG WH-MOVEMENT, NON-ISLAND

Context: Tú piensas que alguien lavó la ropa, pero no estás totalmente seguro de quién fue.

Sentence to evaluate according to the context: ¿Quién piensas que lavó la ropa?

d. LONG WH-MOVEMENT, ISLAND (potential violation)

Context: Alguien lavó la ropa, pero no sé por qué. Después de todo, no estaba tan sucia.

Sentence to evaluate according to the context: ¿Quién no sabes por qué lavó la ropa?

(4) Paradigm 4

a. SHORT WH-MOVEMENT, NON-ISLAND

Context: Alguien piensa que Roberto barrió la cocina.

Sentence to evaluate according to the context: ¿Quién piensa que Roberto barrió la cocina?

b. SHORT WH-MOVEMENT, ISLAND (no violation)

Context: Alguien no sabe por qué Roberto barrió la cocina.

468 Fontes Linguae Vasconum (FLV), 126, julio-diciembre, 2018, 435-471

ISSN: 0046-435X ISSN-e: 2530-5832 
Sentence to evaluate according to the context: ¿Quién no sabe por qué Roberto barrió la cocina?

c. LONG WH-MOVEMENT, NON-ISLAND

Context: Tú piensas que alguien barrió la cocina, pero no estás totalmente seguro de quién fue.

Sentence to evaluate according to the context: ¿Quién piensas que barrió la cocina?

d. LONG WH-MOVEMENT, ISLAND (potential violation)

Context: Alguien barrió la cocina, pero no sé por qué. No parecía muy necesario.

Sentence to evaluate according to the context: ¿Quién no sabes por qué barrió la cocina?

(5) Paradigm 5

a. SHORT WH-MOVEMENT, NON-ISLAND

Context: Alguien piensa que Jorge abrió la puerta.

Sentence to evaluate according to the context: ¿Quién piensa que Jorge abrió la puerta?

b. SHORT WH-MOVEMENT, ISLAND (no violation)

Context: Alguien no sabe por qué Laura abrió la puerta.

Sentence to evaluate according to the context: ¿Quién no sabe por qué Laura abrió la puerta?

C. LONG WH-MOVEMENT, NON-ISLAND

Context: Tú piensas que alguien abrió la puerta, pero no estás totalmente seguro de quién fue.

Sentence to evaluate according to the context: ¿Quién piensas que abrió la puerta?

d. LONG WH-MOVEMENT, ISLAND (potential violation)

Context: Alguien abrió la puerta, pero no sé por qué.

Sentence to evaluate according to the context: ¿Quién no sabes por qué abrió la puerta?

(6) Paradigm 6

a. SHORT WH-MOVEMENT, NON-ISLAND

Context: Alguien piensa que Jorge recibió el premio.

Sentence to evaluate according to the context: ¿Quién piensa que Jorge recibió el premio?

b. SHORT WH-MOVEMENT, ISLAND (no violation)

Context: Alguien no sabe por qué Jorge recibió el premio.

Sentence to evaluate according to the context: ¿Quién no sabe por qué Jorge recibió el premio?

c. LONG WH-MOVEMENT, NON-ISLAND

Context: Tú piensas que alguien recibió el premio, pero no estás totalmente seguro de quién fue.

Sentence to evaluate according to the context: ¿Quién piensas que recibió el premio?

d. LONG WH-MOVEMENT, ISLAND (potential violation)

Context: Alguien recibió el premio, pero no sé por qué. 
(7) Paradigm 7

Sentence to evaluate according to the context: ¿Quién no sabes por qué recibió el premio?

a. SHORT WH-MOVEMENT, NON-ISLAND

Context: Alguien piensa que Santi copió el examen.

Sentence to evaluate according to the context: ¿Quién piensa que Santi copió el examen?

b. SHORT WH-MOVEMENT, ISLAND (no violation)

Context: Alguien no sabe por qué Santi copió el examen. Al fin y al cabo, era muy fácil.

Sentence to evaluate according to the context: ¿Quién no sabe por qué Santi copió el examen?

c. LONG WH-MOVEMENT, NON-ISLAND

Context: Tú piensas que alguien copió el examen, pero no estás totalmente seguro de quién fue.

Sentence to evaluate according to the context: ¿Quién piensas que copió el examen?

d. LONG WH-MOVEMENT, ISLAND (potential violation)

Context: Alguien copió el examen, pero no sé por qué. Después de todo, era muy fácil.

Sentence to evaluate according to the context: ¿Quién no sabes por qué copió el examen?

(8) Paradigm 8

a. SHORT WH-MOVEMENT, NON-ISLAND

Context: Alguien piensa que Pedro pintó la pared.

Sentence to evaluate according to the context: ¿Quién piensa que Pedro pintó la pared?

b. SHORT WH-MOVEMENT, ISLAND (no violation)

Context: Alguien no sabe por qué Pedro pintó la pared. En realidad no se veía tan mal.

Sentence to evaluate according to the context: ¿Quién no sabe por qué Pedro pintó la pared?

c. LONG WH-MOVEMENT, NON-ISLAND

Context: Tú piensas que alguien pintó la pared, pero no estás totalmente seguro de quién fue.

Sentence to evaluate according to the context: ¿Quién piensas que pintó la pared?

d. LONG WH-MOVEMENT, ISLAND (potential violation)

Context: Alguien pintó la pared, pero no sé por qué. Después de todo, no se veía mal.

Sentence to evaluate according to the context: ¿Quién no sabes por qué pintó la pared?

(9) Paradigm 9

a. SHORT WH-MOVEMENT, NON-ISLAND

Context: Alguien piensa que Eduardo robó el dinero.

$470 \quad$ Fontes Linguae Vasconum (FLV), 126, julio-diciembre, 2018, 435-471

ISSN: 0046-435X ISSN-e: 2530-5832 
(10) Paradigm $10^{10}$

Sentence to evaluate according to the context: ¿Quién piensa que Eduardo robó el dinero?

b. SHORT WH-MOVEMENT, ISLAND (no violation)

Context: Alguien no sabe por qué Eduardo robó el dinero. Al fin y al cabo, es rico.

Sentence to evaluate according to the context: ¿Quién no sabe por qué Eduardo robó el dinero?

c. LONG WH-MOVEMENT, NON-ISLAND

Context: Tú piensas que alguien robó el dinero, pero no estás totalmente seguro de quién fue.

Sentence to evaluate according to the context: ¿Quién piensas que robó el dinero?

d. LONG WH-MOVEMENT, ISLAND (potential violation)

Context: Alguien robó el dinero, pero no sé por qué. Después de todo, aquí a nadie le falta de nada.

Sentence to evaluate according to the context: ¿Quién no sabes por qué robó el dinero?

a. SHORT WH-MOVEMENT, NON-ISLAND

Context: Alguien piensa que Julio cortó el árbol.

Sentence to evaluate according to the context: ¿Quién piensa que Julio cortó el árbol?

b. SHORT WH-MOVEMENT, ISLAND (no violation)

Context: Alguien no sabe por qué Julio cortó el árbol. En realidad, no se veía $\tan$ mal.

Sentence to evaluate according to the context: ¿Quién no sabe por qué Julio cortó el árbol?

c. LONG WH-MOVEMENT, NON-ISLAND

Context: Tú piensas que alguien cortó el árbol, pero no estás totalmente seguro de quién fue.

Sentence to evaluate according to the context: ¿Quién piensas que cortó el árbol?

d. LONG WH-MOVEMENT, ISLAND (potential violation)

Context: Alguien cortó el árbol, pero no sé por qué. Después de todo, no se veía tan mal.

Sentence to evaluate according to the context: ¿Quién no sabes por qué cortó el árbol?

10 The English counterpart uses ...pruned the roses instead of ...cortó el árbol 'cut down the tree'. We chose that version for English to avoid adding the particle 'down' to the verb phrase, thus keeping verb phrase length approximately the same across languages and across lexicalizations. 
0000 